Holn $D$ DIN $D$ CH/10093--264
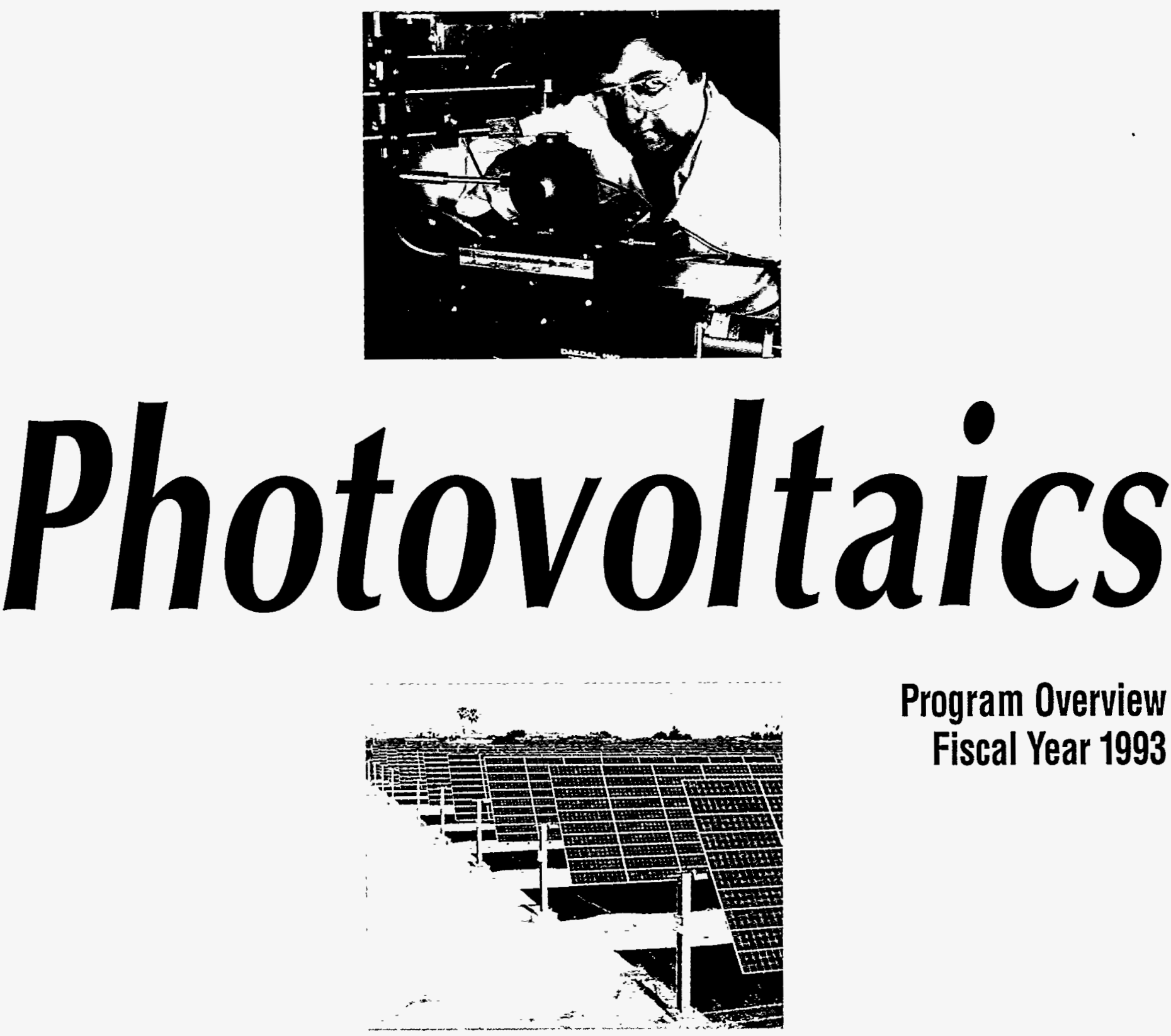

Program Overview

Fiscal Year 1993

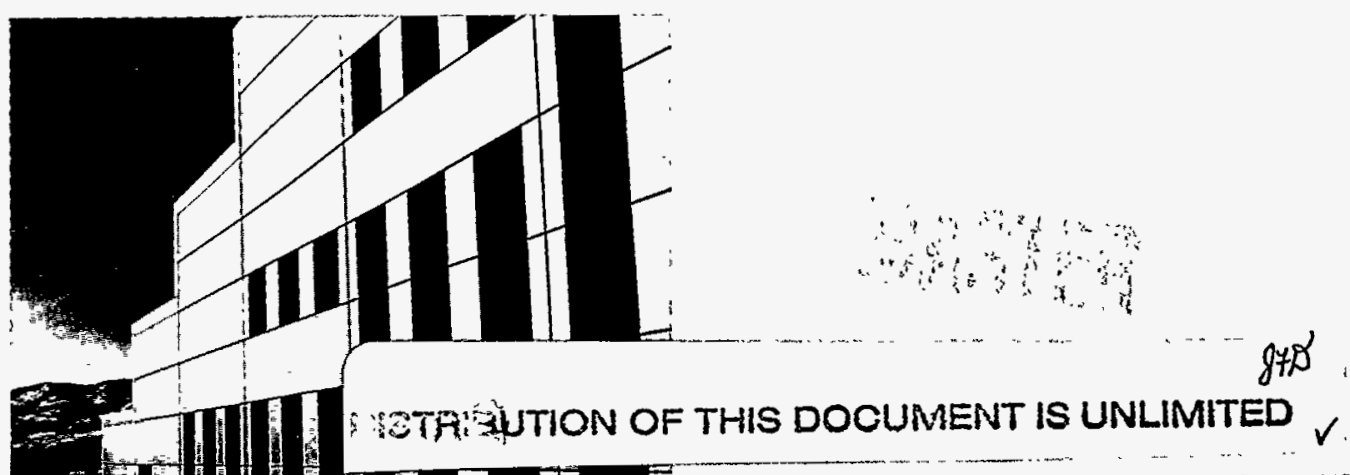




\section{Message from the Director}

As the new century approaches, we in the U.S. Department of Energy (DOE) Photovoltaics Program are increasingly challenged to make a difference to the nation and the world. The Photovoltaics Program promotes the widespread use of photovoltaics (PV), which will reduce the need for fossil fuels and the associated environmental impact of burning those fuels. Meanwhile, the goal of displacing large-scale, $\mathrm{CO}_{2}$-producing electricity generation with $\mathrm{PV}$ is within our reach, thanks to years of DOE collaboration with industry in cost-shared laboratory research, technology development, and system validation. Yet there is still much to do.

Pilot hardware projects in key markets demonstrate that PV works, and that PV can save money and reduce harmful emissions from conventional power plants. But markets must continue to grow if $\mathrm{PV}$ is to make a difference.

Manufacturing capacity, especially for newer, potentially less-expensive PV technologies, is beginning to expand. However, growing markets for large-scale power generation and international applications will demand more factories in the future.

System performance is improving, partly as a result of laboratory research. But we need to incorporate the performance improvements obtained in the laboratory into commercial products to reduce the cost and increase the reliability of PV systems. New PV technologies are being developed that will reduce system costs, much the way new semiconductor chips have improved computational performance in the computer industry. But new PV technologies must mature before they can have significant commercial impact.

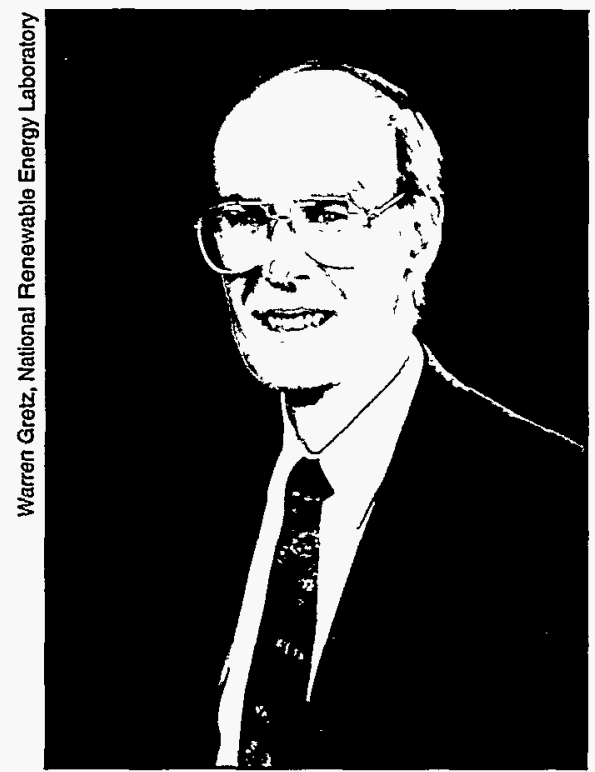

James Rannels
The highlights of our work in Fiscal Year (FY) 1993 presented here illustrate our commitment to move new ideas from the laboratory into production and the marketplace. Working with utilities, industry, other government agencies, and international organizations, the PV Program shares its technical expertise and funds to stimulate markets, expand manufacturing capacity, and improve PV technologies and systems. As we plan for our next 5 years, uppermost in our minds is positioning $P V$ to make a difference in the world.
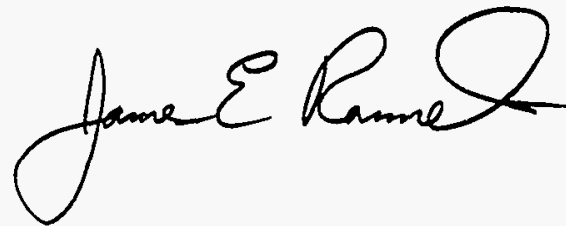

James E. Rannels, Director Photovoltaics Technology Division U.S. Department of Energy, EE-131 Washington, DC 


\section{DISCLAIMER}

Portions of this document may be illegible electronic image products. Images are produced from the best available original document. 


\section{Contents}

\section{PV Program Accomplishments}

\section{PV Systems for Today's Markets Generate Power and}

\section{Experience}

The PV Program shares the cost of installations, supplies technical assistance, and develops analytic tools to expand the market for $P V$.

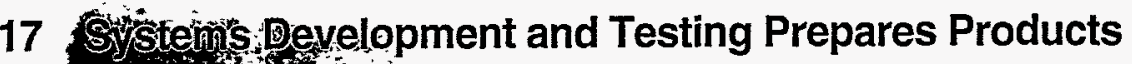
for ivarke

The PV PTog project design, pertornance, and construction.

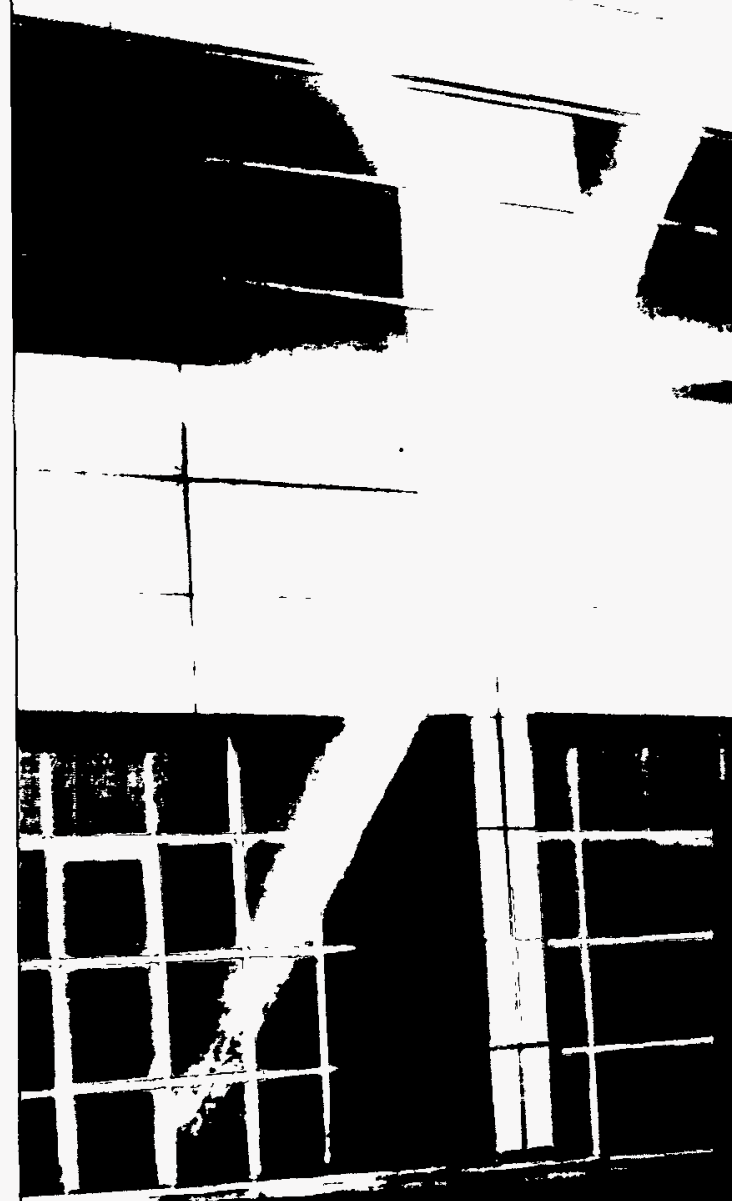

24 Advances in Manưfacturing Hasten Availability of Innovations

The PV Program wojks with industry to transform prototype

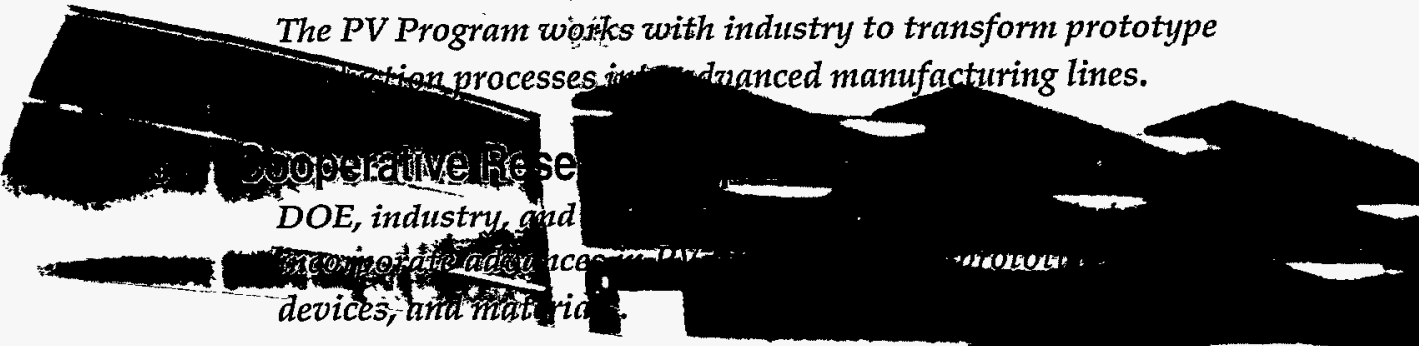

37 Additional Achievements

38 Summary of PV Program S

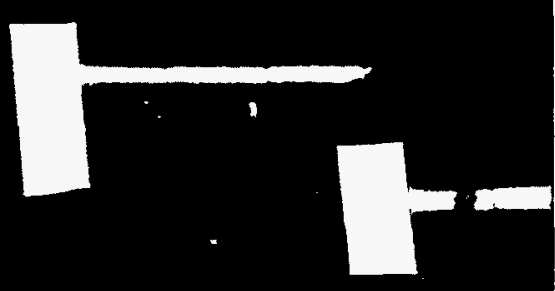

On the Cover-

Top: Energy Conversion Devices (ECD), Inc. improved its manufacturing facility for producing continuous, roll-fo-roll amorphous silicon in FY 1993; photo courtesy of ECD.

Second: PV Program researchers won another RED 100 award in FY 1993 for fabricating a device that maps crystalline defects and grain boundaries in crystalline materials; photo by Warren Gretz, National Renewable Energy Laboxatory.

Third: The Photovoltaics for Utility Scale Applications (PVUSA) project completed construction of a 500-kW power plant at Kerman, California, in FY 1993; photo courtesy of PVUSA.

Bottom (and this page): The PV Program completed construction of the Solar Energy Research Facility in FY 1993; photos by Warren Gretz, National Renewable Energy Laboratory. 


\section{PV Program \\ Accomplishments}

\section{Today's Markets for PV}

- Completed Utility Load-Matching Assessment for 20 utilities and developed spreadsheet program to evaluate PV as a demand-side management option.

- Published Photovoltaic Power As A Utility Service: Guidelines For Livestock Water Pumping.

- Supported commercialization projects for the utility market - Utility Photovoltaic Group and PV for Utilities.

- Published Photovoltaic Systems for Government Agencies and supported Department of Defense and Environmental Protection Agency programs to install PV.

- Published Photovoltaics for Municipal Planners to promote PV in urban areas.

- Began expansion of U.S./Brazilian Rural Electrification Pilot Project in seven Brazilian states, and continued support and technical assistance for projects in Mexico, Central and South America, and Indonesia.

- Published Solar Photovoltaics for Development Applications to promote PV in developing nations.

\section{Systems Development and Testing}

- Continued support for Photovoltaics for Utility-Scale Applications, a project in which utilities are testing the performance of $1.6 \mathrm{MW}$ of PV systems.

- Awarded contracts to teams of researchers and developers to incorporate PV into building and construction products in the PV: Building Opportunities in the U.S. project.

- Expanded balance-of-system test capabilities and research contracts.

\section{Advances in Manufacturing}

- Continued Phase 2A and awarded Phase 3A contracts for Photovoltaics Manufacturing Technology Project. Several of the contractors made advances such as improving continuous-process production lines and producing larger-area PV cells and modules.

- Continued analysis and testing support to manufacturers of concentrating, flat-plate silicon, and thin-film PV modules.

- Improved laboratory capabilities by completing construction of the Solar Energy Research Facility in Golden, Colorado, which is now the premier PV research facility in the world.

\section{Cooperative Research and Development}

- Developed and transferred to industry a technique to produce a thin-film PV cell made of copper indium diselenide with a record-setting efficiency of $15.5 \%$.

- Simplified processing for a $23 \%$ efficient (at $40-80$ suns) concentrator cell made from (float zone) crystalline silicon.

- Funded work at Georgia Institute of Technology leading to the production of a $17.7 \%$ efficient multicrystalline silicon cell.

- Invented a Scanning Defect Mapping System and installed a Spectral Response Laser Scanning System to increase the speed and accuracy of analyses of material samples for the PV industry.

- Supported thin-film contractors, who produced: a 15.8\%-efficient cell made from cadmium telluride; a small-area cell with a stabilized efficiency of $11.2 \%$ made from amorphous silicon; and a $29.5 \%$ efficient cell made from gallium arsenide.

- Conducted Sunrayce '93, involving more than 2000 students in a competition to design and race solar-powered cars. 


\section{PV Systems for Today's Markets Generate Power and Experience}

PV projects installed by utilities, U.S. government agencies, and international organizations add to growing worldwide experience in operating PV systems. Technical and financial support from the PV Program has laid the foundation for many of these projects.

\section{Utility Markets}

Large-scale generation of electric power is the most important long-term market for PV. Because utilities will play a major role in this market, their activities take on a strategic importance.

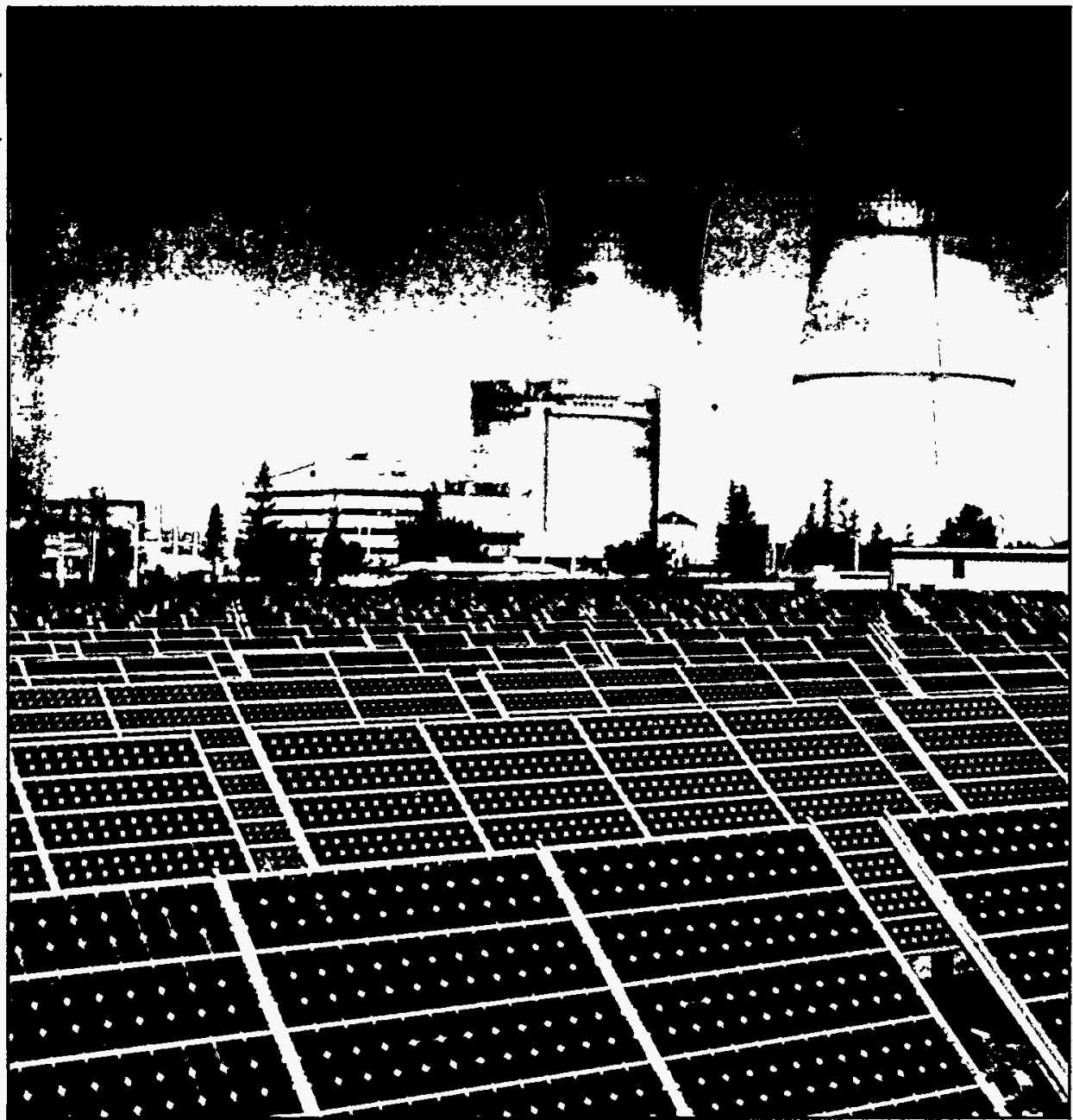

The Sacramento Municipal Utility District operates this 2-MW PV power plant at Rancho Seco, California.
Today's utility projects furnish the experience for tomorrow's large-scale PV markets.

The Sacramento Municipal Utility District (SMUD), for example, recently began a program to promote energy efficiency and a renewable energy supply. The program, started at the request of SMUD's customers, was undertaken to stabilize energy prices and reduce pollution. According to the utility's analysts, the cost benefits of reduced pollution and improved system reliability (accruing over 20 years) are expected to be two-and-a-half times as great as the extra costs of using renewable energy sources instead of natural gas.

SMUD's initiative includes PV for the following market sectors.

\section{Central Station: A 2-MW PV} power plant at Rancho Seco generates electricity for distribution to all SMUD customers from one central location. The operation of this large-scale plant is similar to that of conventional power plants.

\section{Grid Support: A 200-kW PV} system at the Hedge substation Transmission and Distribution Training Yard supports the electricity distribution system. Medium-sized PV systems similar to the Hedge substation supply power to the customers served by the substation. The PV systems help the utility maintain proper voltage and power quality at the substation. 


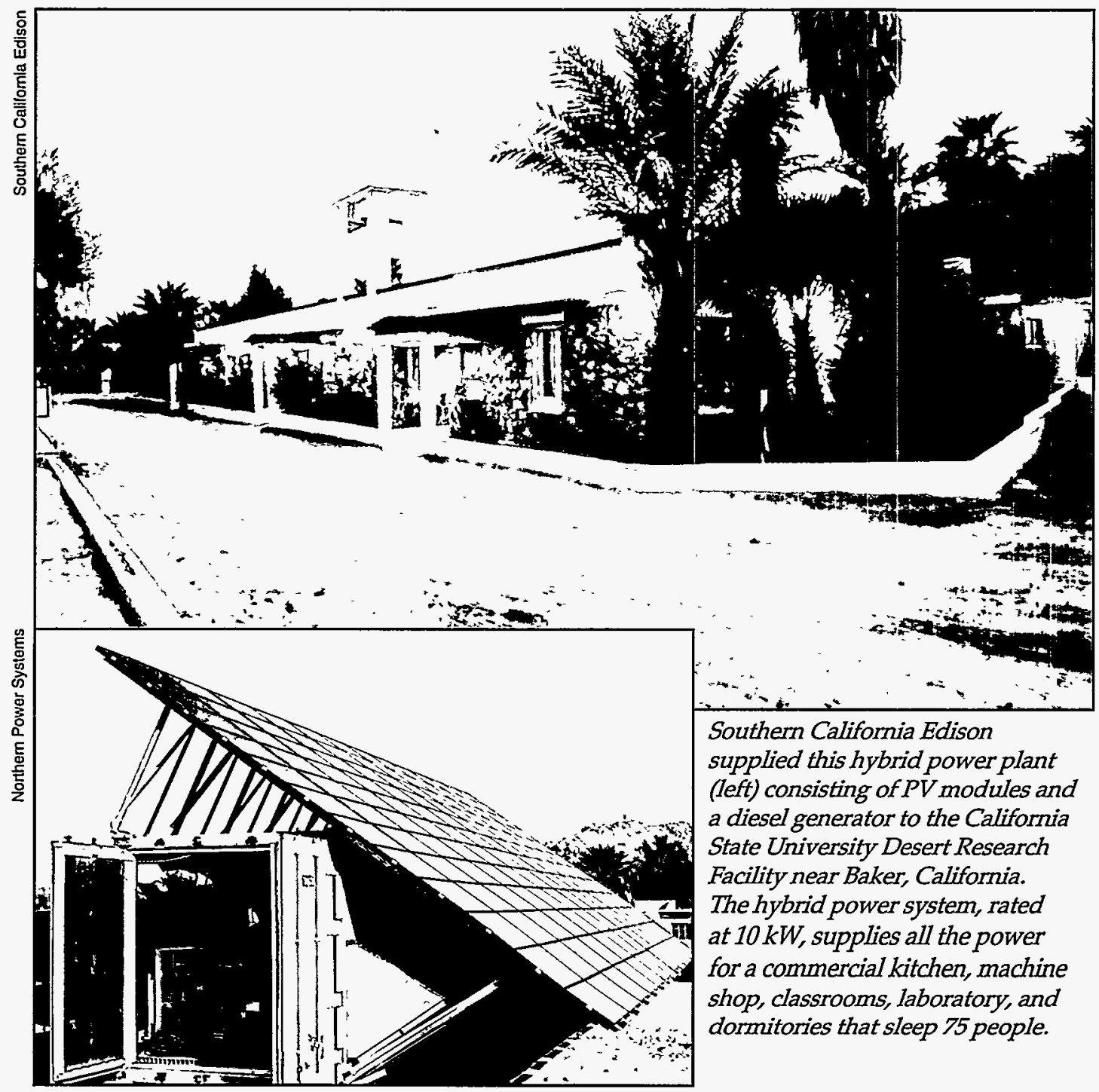

power into the utility's electric grid if the homes do not require the power output from the PV.

5. Off-Grid Systems: Many stand-alone PV systems power emergency telephones and lighting. There are many utility applications where small PV systems are the most economical sources of power.

\section{Electric Vehicle Charging:} A solar "chargeport" charges up to 16 electric vehicles at SMUD's headquarters.

These projects are part of the utility's multiyear plan for the sustained development of grid-connected PV.

Other utilities are also conducting demonstrations of PV. For example, Southern California Edison (SCE) of San Diego, California, has recently begun a number of

\section{Commercial Grid-Connected/} Demand-Side Management: A 40-kW PV system on a SMUD commercial building will help reduce the building's electrical demand. The PV system sized to that particular building can help meet the utility's need for demand-side management (DSM).

\section{Residential Grid-Connected:} More than 100 homes will have PV modules that provide a substantial portion of the electricity requirements of the homes or feed
PV projects. This year SCE built a PV-powered charging station to serve the growing number of electric vehicles in the South Coast Air Quality Management District. Solar chargeports perform double duty by shading cars in parking lots during the day and at the same time providing power to the electric cars or to the utility. The chargeports thus provide service at a time when the overall electric demand on the utility is the greatest. PV Program analysts are now assessing the performance of SCE's chargeports to help utilities 
and manufacturers of electric cars develop this new application of PV for urban areas.

Central and South West Services, Inc. (CSS), in Texas, recently announced a \$10-million, 5-year study of the value of PV to the utility. CSS plans to install, operate, and monitor some

For many utilities involved in the study, PV generation either on the demand or supply side, could help meet their capacity requirements. In FY 1994, 20 additional utilities will participate in an expanded load-matching study. of the most promising gridconnected PV configurations. For example, CSS will install a 300-kW PV system near the end of a distribution feeder to demonstrate the value of PV for grid support. The utility will also attempt to quantify the benefits of generating power with PV near the customer's point of use in five grid-connected systems on homes and on a ranch. In this study, CSS will gain experience with PV technology that it believes will soon be cost-competitive with traditional forms of power generation.

\section{Assessing Benefits of PV for Demand-Side Management}

The PV Program develops and demonstrates methods for utilities to calculate the value of PV to their operations. In FY 1993, for example, researchers at the University of Delaware analyzed the incentives utilities offer for demand-side management options such as demandcontrol devices and compact fluorescent lights. Based on this analysis, they proposed strategies for utilities to use PV for DSM, and then developed a spreadsheet program that evaluates the performance of PV for DSM. They also used load profiles from the local utility, Delmarva Power and Light Co., to develop and test the spreadsheet program. In FY 1994, PV Program analysts will test the spreadsheet program with load profiles from six other utilities. These analysts plan to use the data to develop and publish six case studies of PV for DSM.

Delmarva Power and Light also installed a PV system on a customerservice building in FY 1993. Delmarva will monitor the PV system to verify its belief that PV makes sense for demand-side management. The utility is also working with the PV Program's Building Opportunities in the United States for Photovoltaics (PV:BONUS) initiative to study the benefits of designing and selling PV systems to its customers for use in commercial buildings.

In addition, the PV Program supported a study in FY 1993 of PV's ability to meet utility capacity requirements. Working with 20 utilities, contractors at the State University of New York at Albany compared utility load profiles over the year with the output of hypothetical PV power plants run by the participating utilities. The contractors calculated the output of the hypothetical PV power plants using solar resource data derived from satellite measurements.

The contractors are attempting to determine the amount of time when the output of the PV plants corresponds to large amounts of power use. This potential match between PV output and the utility's load is crucial 
to determining the effective capacityand, hence, the value-of PV.

\section{Offering Stand-Alone PV in Place of Line Extensions}

For more than five years, the PV

Program has supported demonstra-

tions and evaluations of stand-alone

PV systems instead of extending

power lines to remote locations where

power is needed. In FY 1992, PV

Program analysts, together with the

National Association of Regulatory

Utility Commissioners, published a

report on the benefits of using PV in

place of line extensions. The report

was distributed to utilities and utility

regulators.

In FY 1993, the PV Program completed a demonstration of PV hardware for

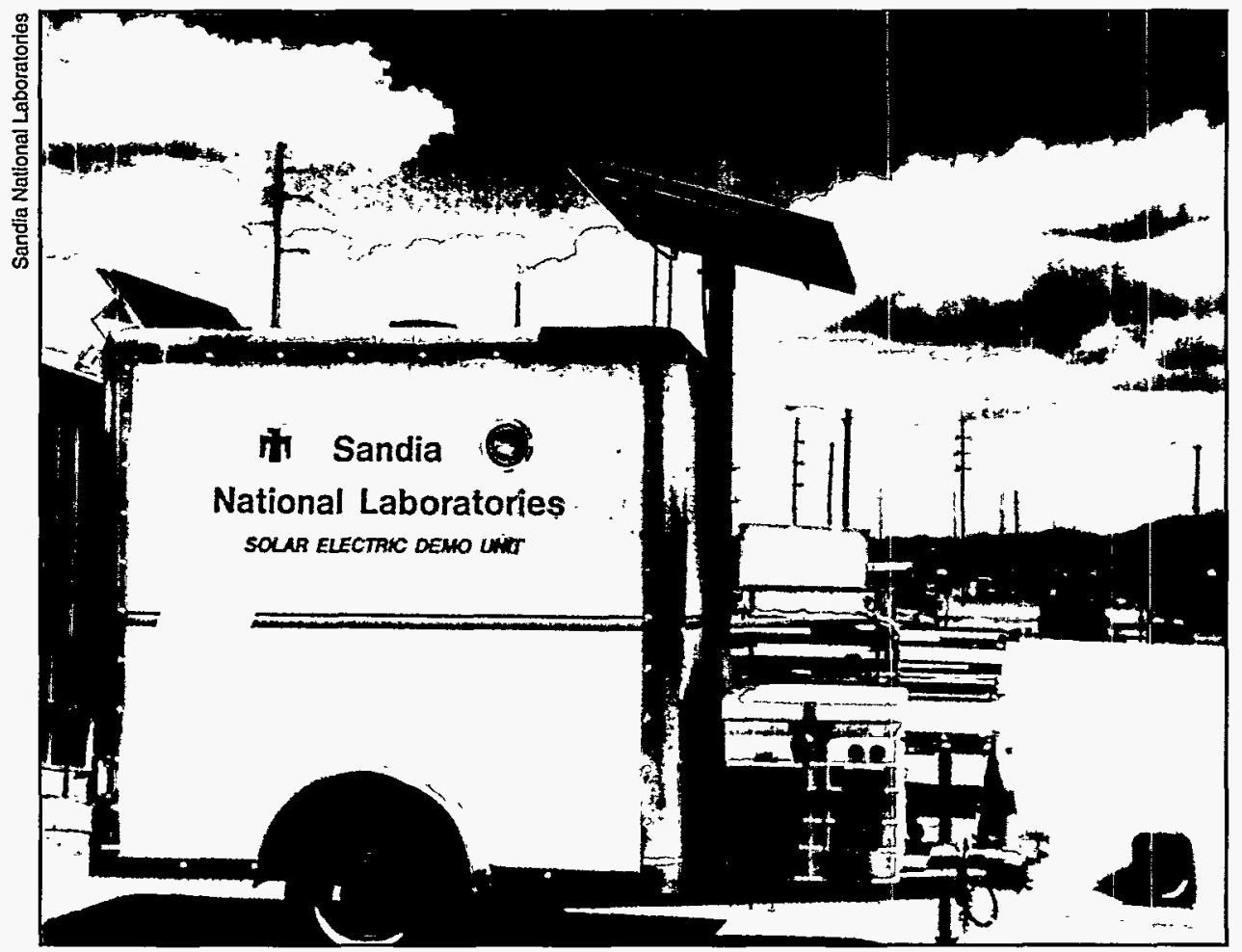

To help the Navajo Tribal Utility Authority show customers the types of PV systems it plans to offer, the PV Program built this demonstration trailer. The PV systems, owned and operated by the utility, are designed to serve both the traditional one-room Navajo hogan and the typical four-room home found on the Navajo reservation. agricultural water pumping, cosponsored by the Electric Power Research Institute (EPRI) and the Western Area Power Administration (WAPA). They published a manual, Photovoltaic Power as a Utility Service: Guidelines for Livestock Water Pumping, incorporating the technical and institutional lessons learned in the project. The manual will help utilities design programs offering PV instead of costly power line extensions.

Idaho Power Company is one of several utilities that already offer PV in place of line extensions. Idaho Power installs, owns, and maintains PV systems in locations where it is more costly to extend a power line. The utility charges the customer a fixed monthly facilities fee that covers its expenses rather than billing for energy used. The company's PV services extent to parts of Idaho, Oregon, and Nevada, and include remote homes, vacation homes, stock watering wells, sign lighting, and communication equipment.

The Navajo Tribal Utility Authority, another utility which provides service to remote areas, is working with WAPA and DOE to offer PV systems rather than extend power lines to a large number of its customers who live in remote locations. The Navajo utility is training local workers to install, operate, and maintain the equipment rather than relying on contract workers from Albuquerque, New Mexico, or Tucson, Arizona. 


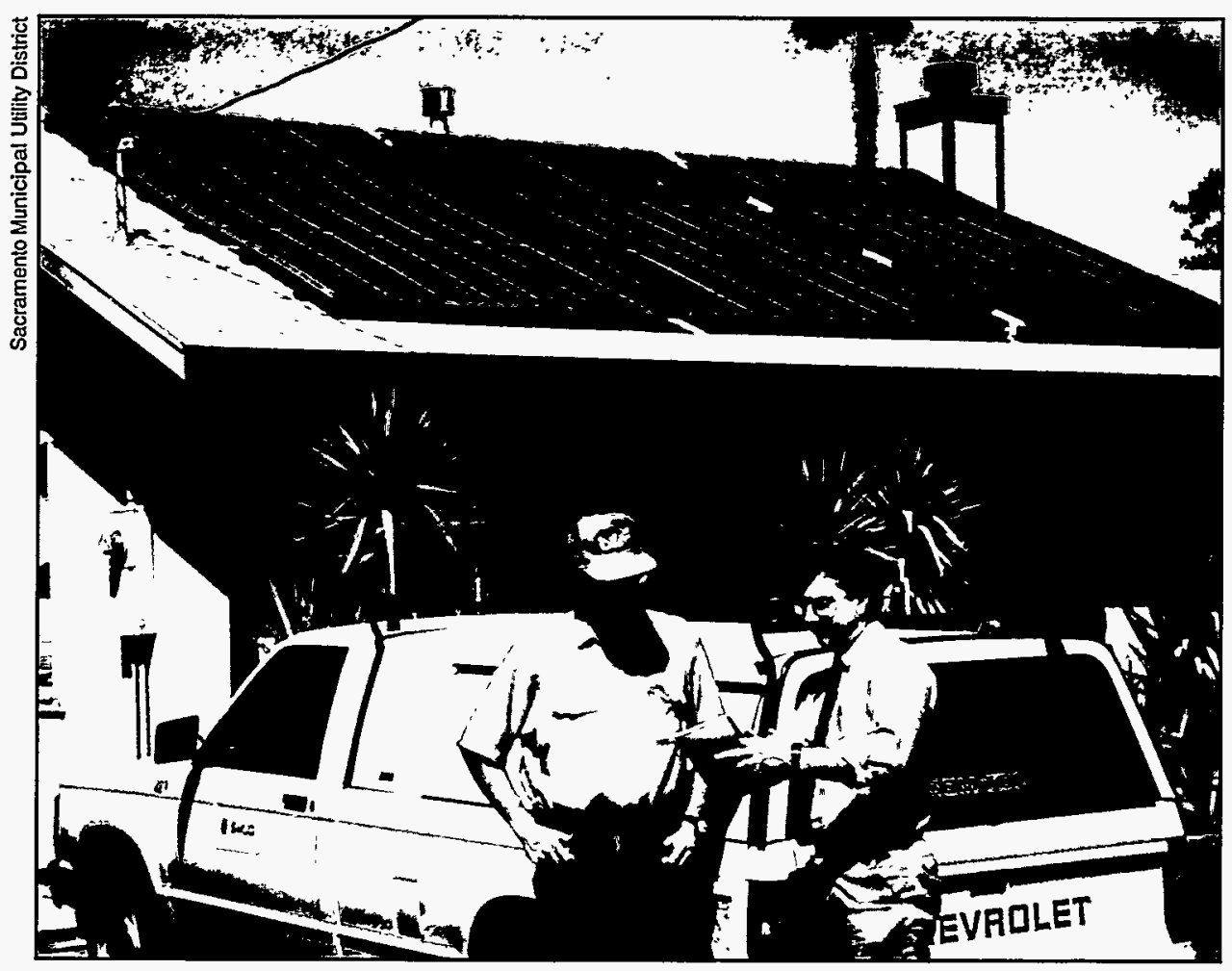

The Sacramento Municipal Utility District has adopted its own version of "green pricing." Under this program, Sacramento homeowners can agree to a 15\% surcharge on their utility bills when the utility installs a PV system on their homes. SMUD owns and operates the 4-kWPV systems installed on its customers' homes.

\section{Developing New Ways to Fund PV Projects}

Many citizens, concerned about global warming and other effects of burning fossil fuels, have asked their utilities to speed up the use of renewables such as PV. Some of them are willing to pay extra to see progress come sooner.

In Gainesville, Florida, for example, a grandmother began a process that would lead several utilities to try a new method for funding the development of renewables known as "green pricing." She told her utility she would be willing to pay a little extra on her utility bill each month to assure her grandchildren a cleaner world.
In green pricing, customers make a one-time contribution to a renewable energy fund or agree to pay a little extra on their utility bill each month. Some utilities that have adopted green pricing, such as Public Service Company of Colorado, match the customers' contributions up to funding levels normally spent developing other resources such as coal and natural gas.

\section{Implementing a Strategy for Commercialization}

The PV Program is supporting the development of a new strategy to commercialize PV through the Utility Photovoltaic Group (UPVG). The UPVG is an organization of 70 utilities that work together to advance 
cost-effective and high-value uses of PV for utilities. UPVG activities include publishing a newsletter, sponsoring workshops, and supporting five active working groups.

The UPVG newsletter, $P V$ Vision, informs members about the latest applications of new PV technology and how other utilities are using PV. The newsletter provides details on relevant legislative activities and progress reports from UPVG workshops and working groups.

UPVG working groups, led by staff from member utilities, have specific tasks. In FY 1993, for example, the Technology Transfer and Member Development Work Group conducted three workshops. One workshop focused on PV for transmission and distribution applications, and another focused on PV for remote homes and water pumping. A third workshop provided general information about PV.

The Applications and Markets Work Group is reviewing market studies and surveying member utilities to quantify PV markets by application. The Engineering and Demonstrations Work Group supports utilities in the engineering and demonstration of PV systems. The Planning and Evaluation Work Group is improving standardized utility planning tools to evaluate the nontraditional benefits of PV such as reducing harmful emissions. Finally, the Commercialization Strategies Work Group will recommend strategies and policies that accelerate the use of PV systems by utilities.
The PV Program also funds state working groups for the organization PV for Utilities (PV4U). Twelve states now have PV4U working groups that bring together diverse organizations within a state to influence legislation, encourage utilities to consider PV, and provide information to decisionmakers.

\section{Government Markets}

The U.S. government, as well as state and local governments, is a big consumer of electricity. These same organizations could use PV systems to help operate their facilities. In FY 1993, the PV Program updated and distributed a popular booklet first published in the 1980s, Photovoltaic Systems for Government Agencies, to increase the use of PV by government agencies. The new information and updated case studies in the booklet help government employees decide where to use PV in their operations.

\section{Reducing Fuel Consumption at Defense Facilities}

The U.S. Department of Defense (DOD), the largest single energy user in the world, is working with DOE and the U.S. Environmental Protection Agency (U.S. EPA) to install $100 \mathrm{MW}$ of cost-effective renewable energy by 1996. By that date, DOD will have invested more than $\$ 16$ million in pilot projects designed to identify, evaluate, and install PV systems at military facilities.

The first DOD projects, starting in FY 1994, will range in size from 20 to $175 \mathrm{~kW}$. They will consist of pilot 


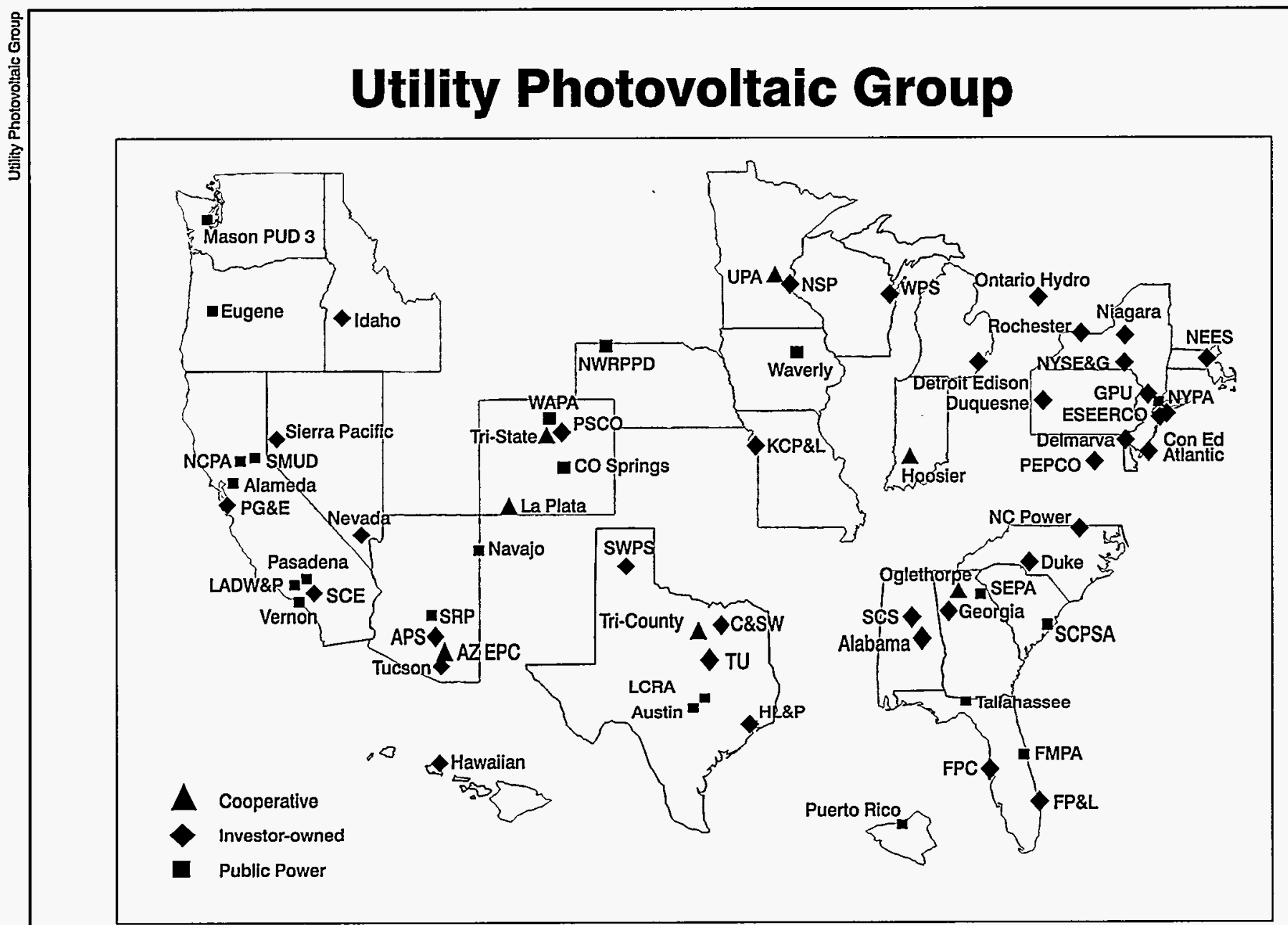

1. Alabama Power Company

2. Alameda Bureau of Electricity

3. American Public Power Association

4. Arizona Electric Power Cooperative

5. Arizona Public Service Company

6. Atlantic City Electric Company

7. City of Austin Electric Department

8. Central and South West Services

9. Colorado Springs Utilities

10. Consolidated Edison Co. of N.Y.

11. Delmarva Power \& Light Co.

12. Detroit Edison Company

13. Duke Power Company, Inc.

14. Duquesne Light Company

15. Edison Electric Institute

16. Empire State Elec. Energy Res. Corp.

17. Eugene Water and Electric Board

18. Florida Municipal Power Agency

19. Florida Power \& Light Company

20. Florida Power Corporation

21. GPU Service Corporation

22. Georgia Power Company

23. Hawalian Electric Company

\section{UPVG Members}

24. Hoosier Energy REC, Inc.

25. Houston Lighting \& Power Co.

26. Idaho Power Company

27. Kansas City Power \& Light Co.

28. La Plata Electric Association

29. Los Angeles Dept. of Water \& Power

30. Lower Colorado River Authority

31. Mason County Public Util. Dist. \#3

32. National Rural Elec. Co-op. Assn.

33. Navajo Tribal Utility Authority

34. Nevada Power company

35. New England Electric Power Co.

36. New York Power Authority

37. New York State Electric \& Gas Corp.

38. Niagara Mohawk Power Corp.

39. North Carolina Power Company

40. Northern California Power Agency

41. Northern States Power Company

42. Northwest Rural Public Power Dist.

43. Oglethorpe Power Corporation

44. Ontario Hydro

45. Pacific Gas \& Electric Company

46. Pasadena Water \& Power Dept.
47. Potomac Electric Power Co. 48. Public Service Co. of Colorado 49. Puerto Rico Electric Power Auth. 50. Rochester Gas \& Electric Corp. 51. Sacramento Municipal Utility Dist. 52. Salt River Project

53. Sierra Pacific Power Company 54. South Carolina Public Service Auth. 55. Southeastern Power Administration 56. Southern California Edison 57. Southern Company Services 58. Southwestern Public Service Co. 59. City of Tallahassee Electric Dept. 60. TU Electric

61. Tri-County Electric Cooperative 62. Tri-State G\&T Association

63. United Power Association 64. City of Vernon Light \& Power Dept. 65. Waverly Light \& Power 66. Western Area Power Administration 67. Wisconsin Public Service Co.

HONORARY MEMBER

Electric Power Research Institute 


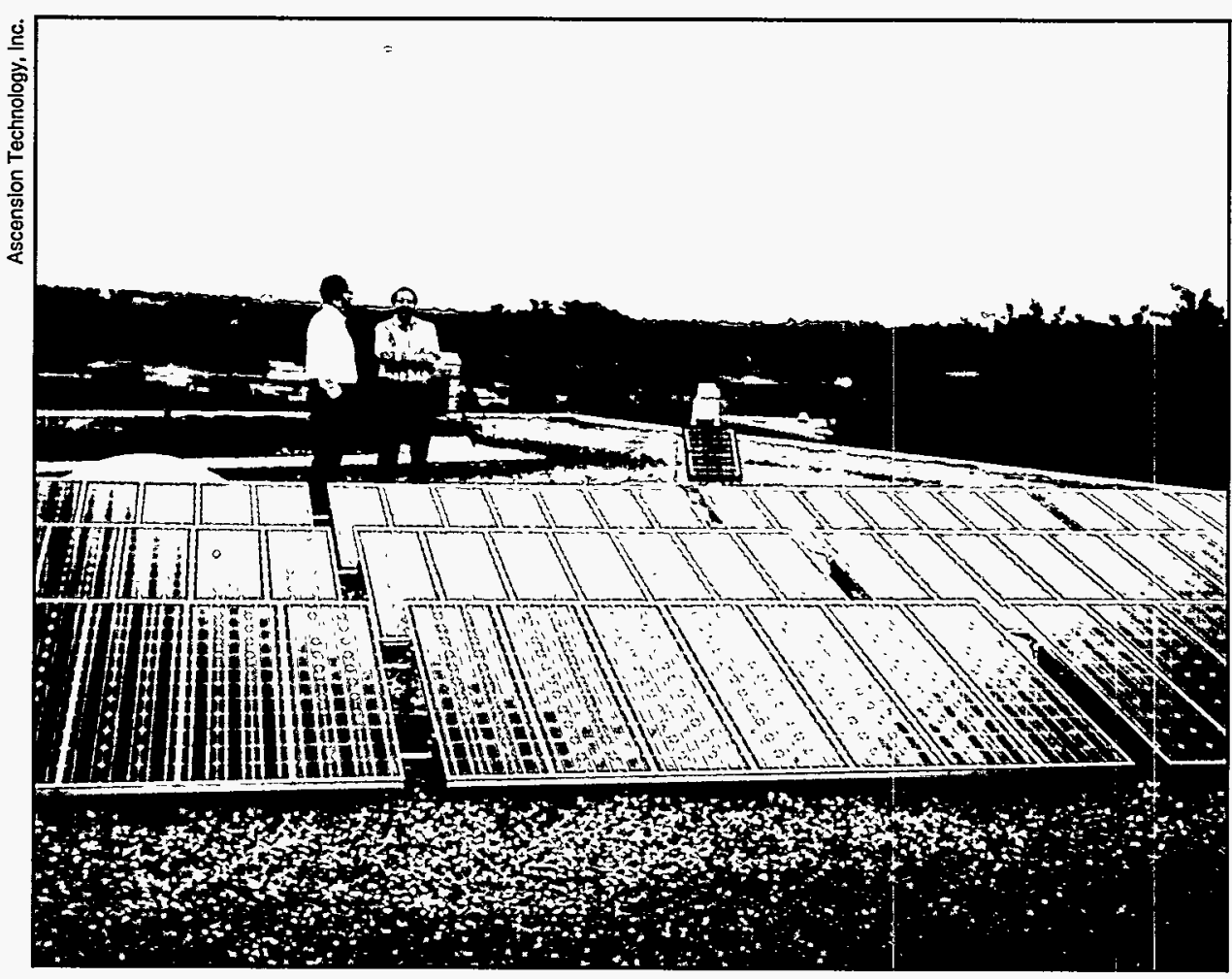

Northern States Power research engineers examine their 4-kW PV system on Compar Corporation's roof in Minnetonka, Minnesota. The demand-side management system is part of EPA's nationwide program to demonstrate renewable energy technologies.

projects using PV to extend the service life of transmission and distribution systems, and also in applications of hybrid PV-diesel generator systems.

The second group of DOD projects includes larger, $50-\mathrm{kW}$ systems that can be connected together for applications up to $500 \mathrm{~kW}$. This size range represents the bulk of hybrid and grid-support applications in DOD, as well as in other government agencies. However, power processing and control systems for these projects must be custom-made, which is expensive and time consuming.

To make these prototype processing and control systems more available and less expensive for larger hybrid and grid-support applications, DOD and DOE support their design, development, and testing. The processing and control systems now under development will meet both military and utility requirements.

\section{Demonstrating Reductions in Air Pollution}

The U.S. EPA joined with 11 utilities in FY 1993 to get first-hand information on the potential of PV to improve air quality, installing 16 PV systems on residential and commercial buildings. The agency will collect data from the systems for at least one year to determine PV's role in national efforts to improve air quality. The data also help utilities evaluate PV as a way to manage demand.

For each utility site selected in FY 1993, U.S. EPA's contractor, Ascension Technologies, Inc., provided hardware, monitored instruments, and assisted in planning, data retrieval, and analysis. The utilities provided the load and emissions data needed to calculate the impact of PV on regional air quality. After one year of monitoring, U.S. EPA will withdraw and the PV system will belong to the utility. In FY 1994, however, the agency is extending the project, joining with the Electric Power Research Institute (EPRI) and another 11 utilities to install PV systems on additional commercial and industrial buildings.

\section{Providing Services on Public Lands}

Federal agencies are under increasing pressure to provide services requiring electricity on public lands they administer. These lands are often 
PV makes sense in urban areas because installing power lines, transformers, and meters can cost thousands of dollars, even for relatively small applications.

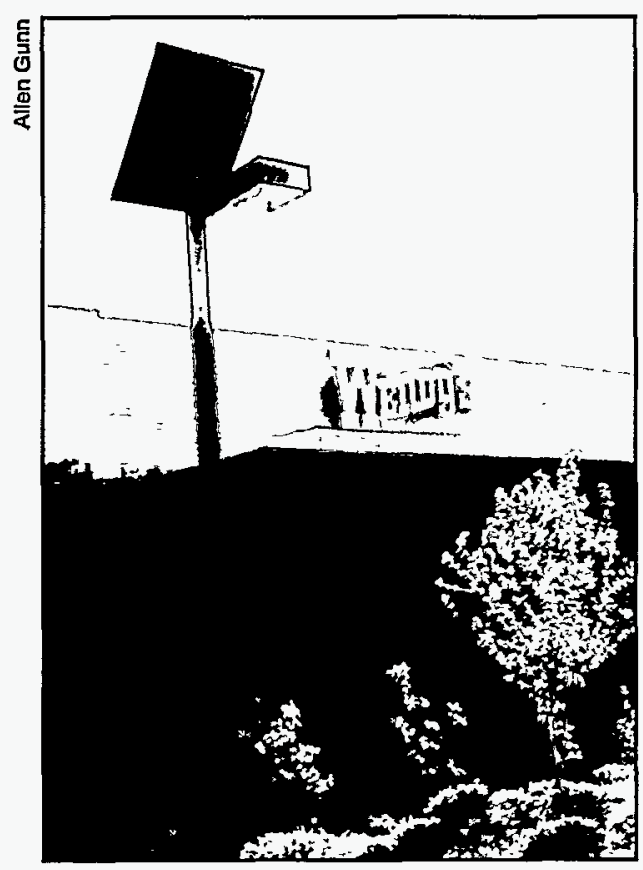

Three stand-alone PV systems provide power to parking lot lights at this restaurant in Atlanta, Georgia. The systems are part of a test project of $P V$ lighting systems at fast-food restaurants. environmentally sensitive or are located near designated wilderness areas, far from utility power lines.

Many federal agencies, such as the National Park Service, the Bureau of Land Management, the Fish and Wildlife Service, and the Forest Service, operate engine generators running on diesel fuel to provide electrical service. Unfortunately, engine generators are noisy, smokey, and demand frequent refueling and maintenance. The environmental impacts on these sensitive lands increase when electrical loads grow and more generators are added. In contrast, PV systems reduce longterm costs and environmental impacts when used to replace or augment engine generators on park lands.

Several federal agencies are installing PV systems to generate electricity in environmentally sensitive areas. The National Park Service, for example, uses a computer-assisted design package to assemble PV systems for its remote sites, and also makes the package available to other agencies. Using these analytical tools, the Park Service identified PV as the least expensive way to power the new Cholla Campground in Arizona's Tonto National Forest. The Park Service also uses PV together with careful energy use to limit the environmental impacts of providing electricity to visitors in the Channel Islands National Park in California.

The PV Program helps federal agencies decide if PV is the right source of power for specific applications on public lands. PV Program scientists provide agency personnel with data on the local solar resource, the load requirements for the application, and alternative power sources. PV Program engineers then present a set of specific recommendations.

\section{Saving Money with Urban Applications}

To increase the use of PV in urban areas, the PV Program published Photovoltaics for Municipal Planners in FY 1993. This document lists 14 case studies of how municipal governments use PV. Based on a survey of 65 cities in 24 states, the report provides other municipal governments with data on PV cost, performance, and reliability.

PV makes sense in urban areas because installing power lines, transformers, and meters can cost thousands of dollars, even for relatively small applications.

PV companies also provide jobs to local economies. Several state and local governments therefore encourage PV companies to locate within their jurisdictions to promote economic development. For example, the State of Virginia will provide up to $\$ 22.5$ million between 1995 and 1999 to PV module manufacturers who build factories in the state. One manufacturer, United Solar Systems Corporation, announced plans to build a $\$ 30$ million, $7,905-\mathrm{m}^{2}\left(85,000-\mathrm{ft}^{2}\right)$ PV module manufacturing facility in Virginia in 1994. 


\section{International Markets}

Today, about half of the population of the developing world lives without adequate electrical power supplies. Demand for electricity increases at $7 \%$ per year in the Third World. Some of this increasing demand can be served by PV.

The PV Program helps U.S. PV companies reach these growing international markets by leveraging funds and lowering institutional barriers to international trade in PV technology. DOE shares the cost of pilot installations, and PV Program personnel help perform site assessments, develop project evaluation criteria, write technical specifications for projects,

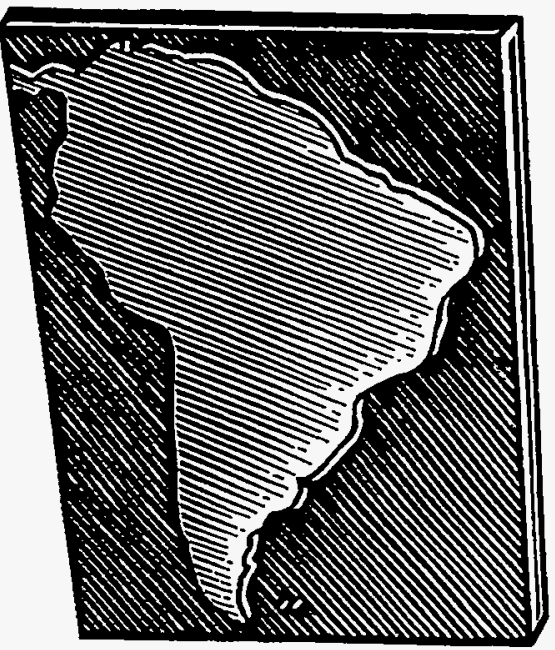
and conduct workshops and training seminars for international PV projects.

\section{Extending PV Rural Electrification in Brazil}

In FY 1993, DOE and the Federal Republic of Brazil began working together to bring electricity to rural communities in Brazil for the first time by using PV. The first phase of this pilot project began in December 1992 with installations of lighting for streets and buildings. In this first phase, PV modules will power electric lights in 450 homes, schools, and public spaces in rural areas in the state of Ceard, Brazil, where nearly $40 \%$ of the population lacks electricity. Lighting for an additional 200 homes and 150 public areas will be installed in the state of Pernambuco.

In the second phase of the project, PV systems will be installed in five additional Brazilian states and will demonstrate a larger variety of applications. This second phase is also designed to further develop the infrastructure for marketing, distributing, and maintaining PV systems in Brazil. DOE will solicit proposals from the U.S. PV industry for specific projects including a PV-wind-battery-diesel hybrid for a fishing village; agricultural water pumping and farm home lighting; solar home demonstrations; a PV-diesel hybrid for another village; and systems for health clinics, schools, community water supplies, radio telephones, and community centers. DOE will contribute about $\$ 1.3$ million toward the estimated $\$ 3$ million cost of the project's second phase in FY 1994.

\section{Providing Technical Assistance}

Drawing on its experience with PV in the developing world, the PV Program will publish Solar Photovoltaics for Development Applications, a manual on PV for individuals and groups specializing in development activities, in FY 1994. The document highlights projects from 20 countries, outlining the benefits of PV systems for water supplies, lighting and residential power, health facilities, community projects, business uses, and communications.

One of the projects highlighted in the manual is the Eastern Islands Pilot Project, in which staff from the PV Program's Design Assistance Center at Sandia National Laboratories (Sandia) 

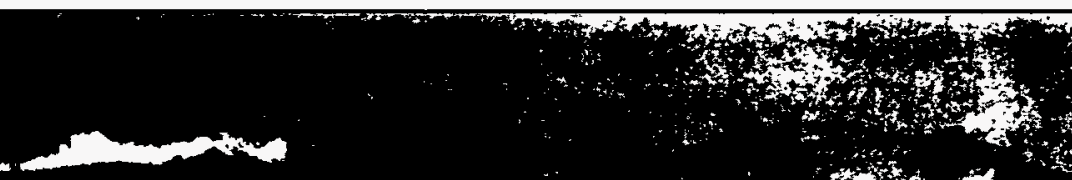

$+\infty$

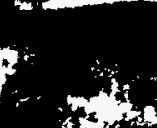

$x^{2}$

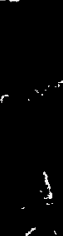

$x_{1}$

$\Rightarrow$

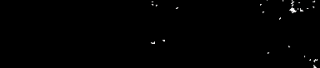

-

in nit

$\therefore x$
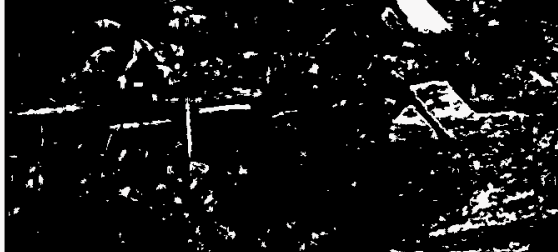

(3)
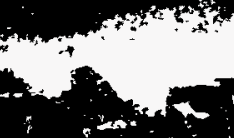

son
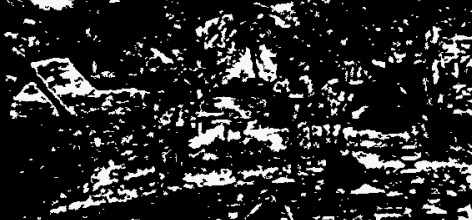

t.
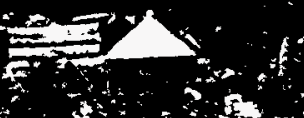

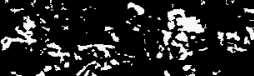

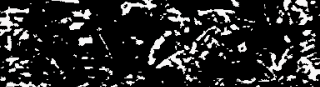

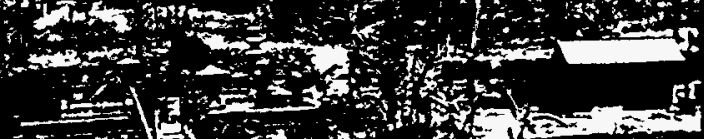

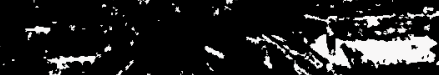
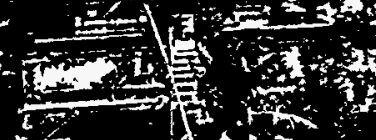

(n)

A $x^{2}+2$
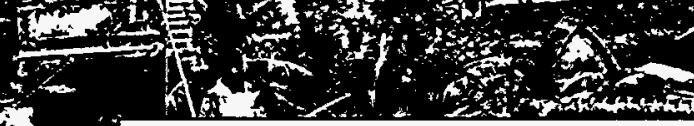

2.

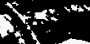

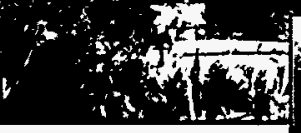

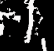

:

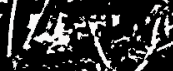

L

Hybrid power plants, consisting of $P V$ modules, a wind turbine, and a diesel generator, serve 2000 people in the villages of Julingan and Tanglad in Indonesia. These plants, rated at $100 \mathrm{kWh}$ per day, were built to demonstrate this hybrid technology for the government of Indonesia's Eastern Islands Pilot Project. Under this project, 50 more villages in the Eastern Islands will receive power from renewable energy such as $P V$.

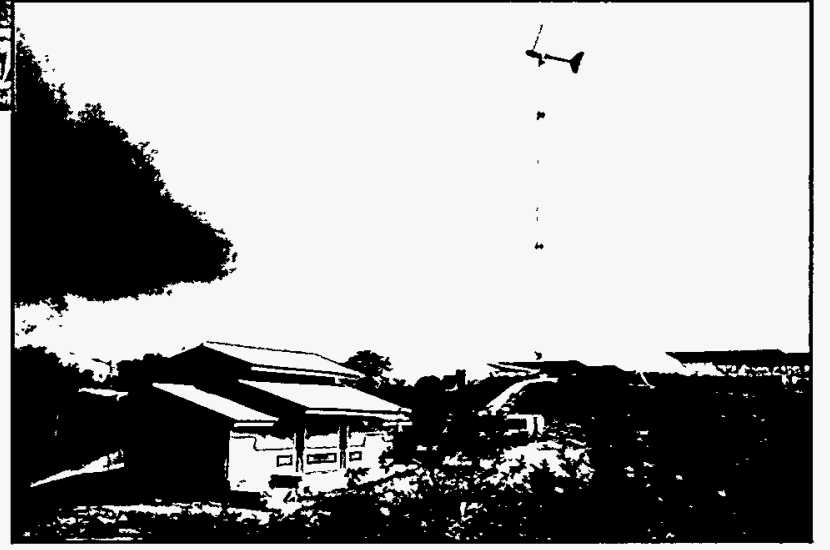

PV Program technical support for these international projects includes monitoring project performance to improve system designs. For example, as part of a cooperative project (called PROCER) between $\mathrm{DOE}$ and the government of Mexico, the PV Program

in Albuquerque, New Mexico, worked with U.S. industry partners and the Indonesian government to survey 20 villages for a rural-electrification initiative in that country. Using a satellite-based global positioning system and databases from a geographic information system, the staff mapped two villages per day in remote areas of Indonesia. The maps show the locations of buildings, roads, and geographic features that can help engineers size PV-diesel hybrid power systems.

Designers can also use these maps to lay out power distribution plans for Indonesian villages with populations ranging from 1000 to 3000 . supplied instruments for collecting data from a PV-wind-diesel hybrid power system in the village of Xcalak in the Yucatan. The data will help designers of $P V$ and hybrid projects being developed in a number of other locations around the world.

In addition, the PV Program sponsored workshops in FY 1993 for utilities, industry, and other users of PV systems in Guatemala, Honduras, Mexico, and Bolivia. Often these workshops provide the information necessary for foreign utilities to undertake their own PV installations. In Guatemala, for example, the 
Guatemalan National Rural Electric

Cooperative Association, with funding from $\mathrm{DOE}$, is incorporating renewable energy into its Productive Uses of Electricity program. This year the first of three Guatemalan villages received PV water pumping and lighting for 40 homes.
In Honduras, PV systems now serve 15 businesses, 31 homes, and five community buildings, thanks to a cooperative effort by the U.S. Peace Corps, Enersol Associates, and the PV Program. In fact, the Peace Corps in Honduras routinely uses $\mathrm{PV}$ technology to promote economic development.

\section{The PV Industry Meets the Challenge of Water Purification}

According to the World Health Organization, the biggest health problems of the developing world can be addressed by providing clean drinking water. Several companies have adapted commercial water treatment systems to operate on PV.
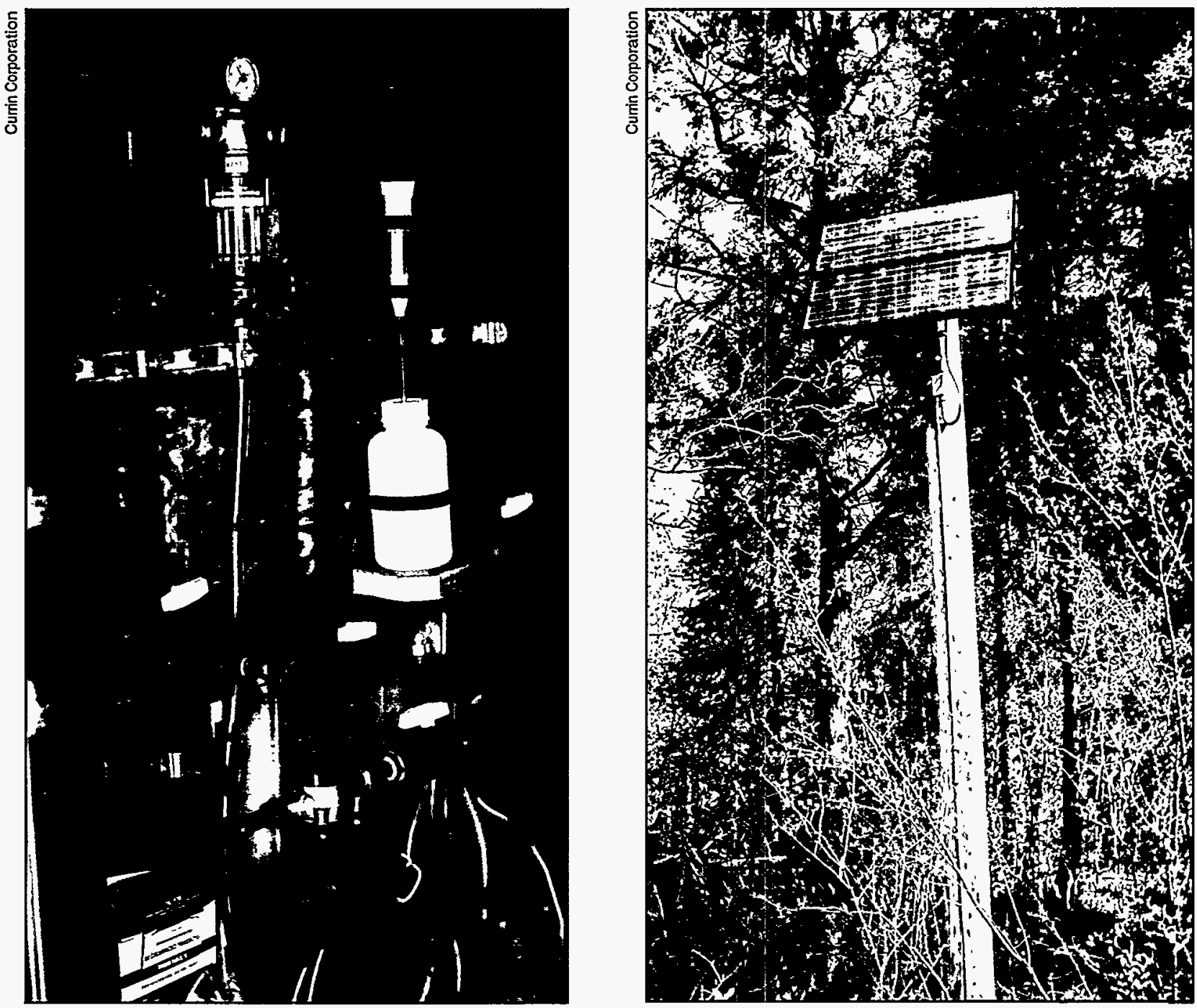

A 120-W PV array powers this water pumping and disinfectant system for a campground at Pictured Rocks National Lakeshore, in Michigan. Having demonstrated their performance in the United States, these water pumping systems are now being marketed in Guatemala and Costa Rica. 


\section{Systems Development and Testing Prepares Products for Market}

Utilities, industry, and consumers want electrical generating systems that are completely reliable. The PV Program helps industry integrate emerging PV cell and module technologies into complete energygenerating systems.

\section{Photovoltaics for Utility-Scale Applications}

Seven states and more than 10 utilities support seven PVUSA test sites across the country.
Utilities are working with industry to evaluate new and promising PV technologies through Photovoltaics for Utility-Scale Applications (PVUSA). PVUSA is a joint venture between DOE, EPRI, the California Energy Commission, DOD, Pacific Gas and Electric Company (PG\&E), and a growing number of other utilities. It also tests and evaluates data from PV systems.

So far, the PVUSA program has installed 1.6 MW of PV at test sites around the country. In its first phase, PVUSA obtained 11 systems totalling more than $900 \mathrm{~kW}$ of peak capacity, which were purchased for about $\$ 18$ million (\$7.8 million from DOE). Nearly every PV company in the United States participated in the first phase, installing PV systems using

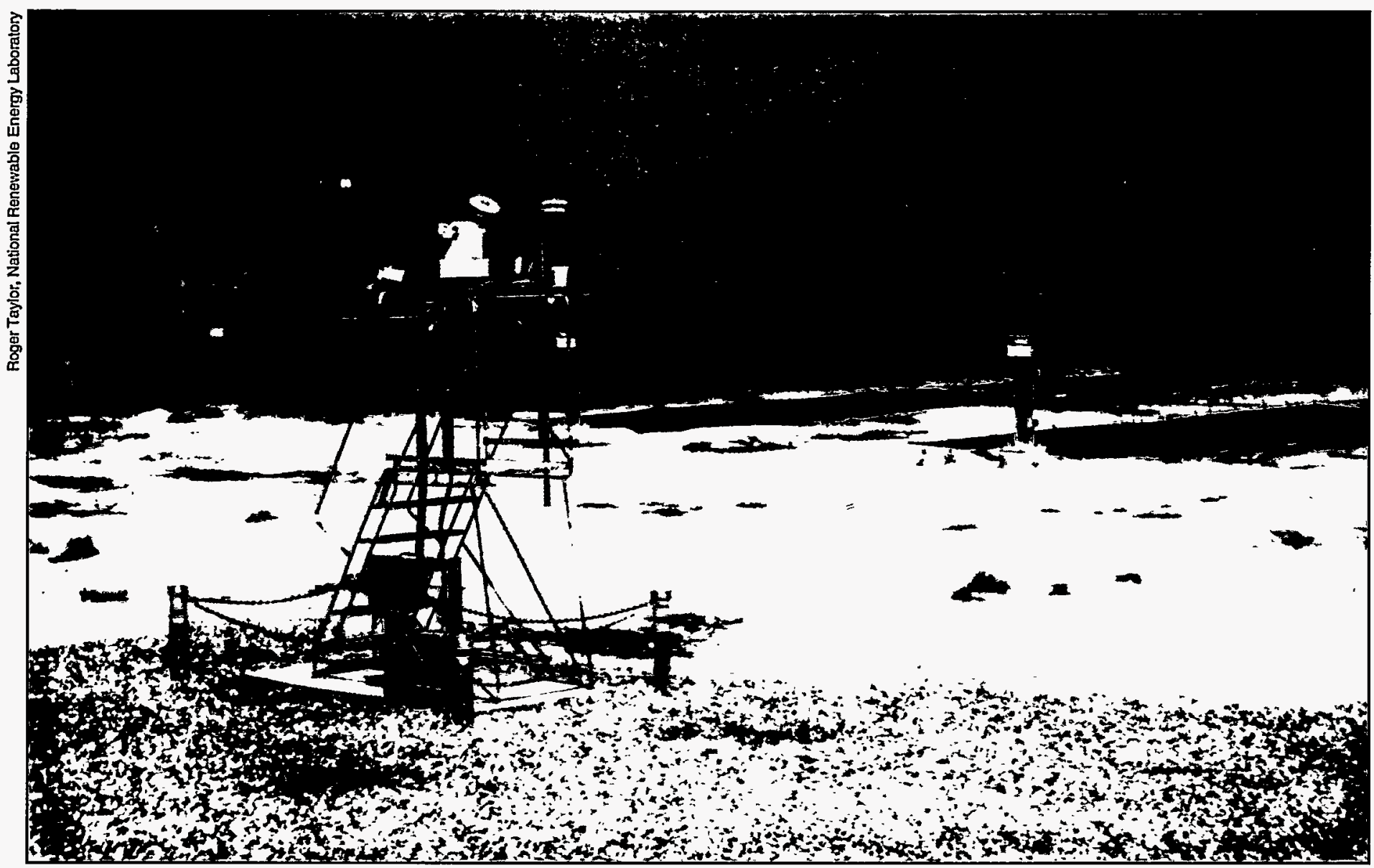

This PV plant operated by PVUSA at the Kerman substation near Fresno, California, provides support to the local electrical grid owned by Pacific Gas \& Electric Company. It began operating in April 1993, just 6 months after construction began, demonstrating that extra generation can be added quickly by installing $P V$. 
both established and emerging PV technologies.

Phase two of PVUSA consists of two projects that provide grid support to utilities. The largest of the two projects consists of a $500-\mathrm{kW}$ system connected to PG\&E's Kerman substation near Fresno, California. PG\&E needed extra generation at the Kerman substation because electrical demand, which peaks on hot summer afternoons, had surpassed the substation's capacity. Electricity from the 500-kW PV system helps offset these afternoon peaks and thus effectively reduces the load on the substation to a level below its capacity.

PG\&E analysts suggest the PV plant will benefit the utility in several other ways. For example, the PV system will delay the need for upgrading the station, reduce electrical losses in the transmission lines between the power plants serving Kerman and the substation, and reduce air pollution. PG\&E engineers are attempting to measure these and other benefits of using PV at their facilities. The engineers will then

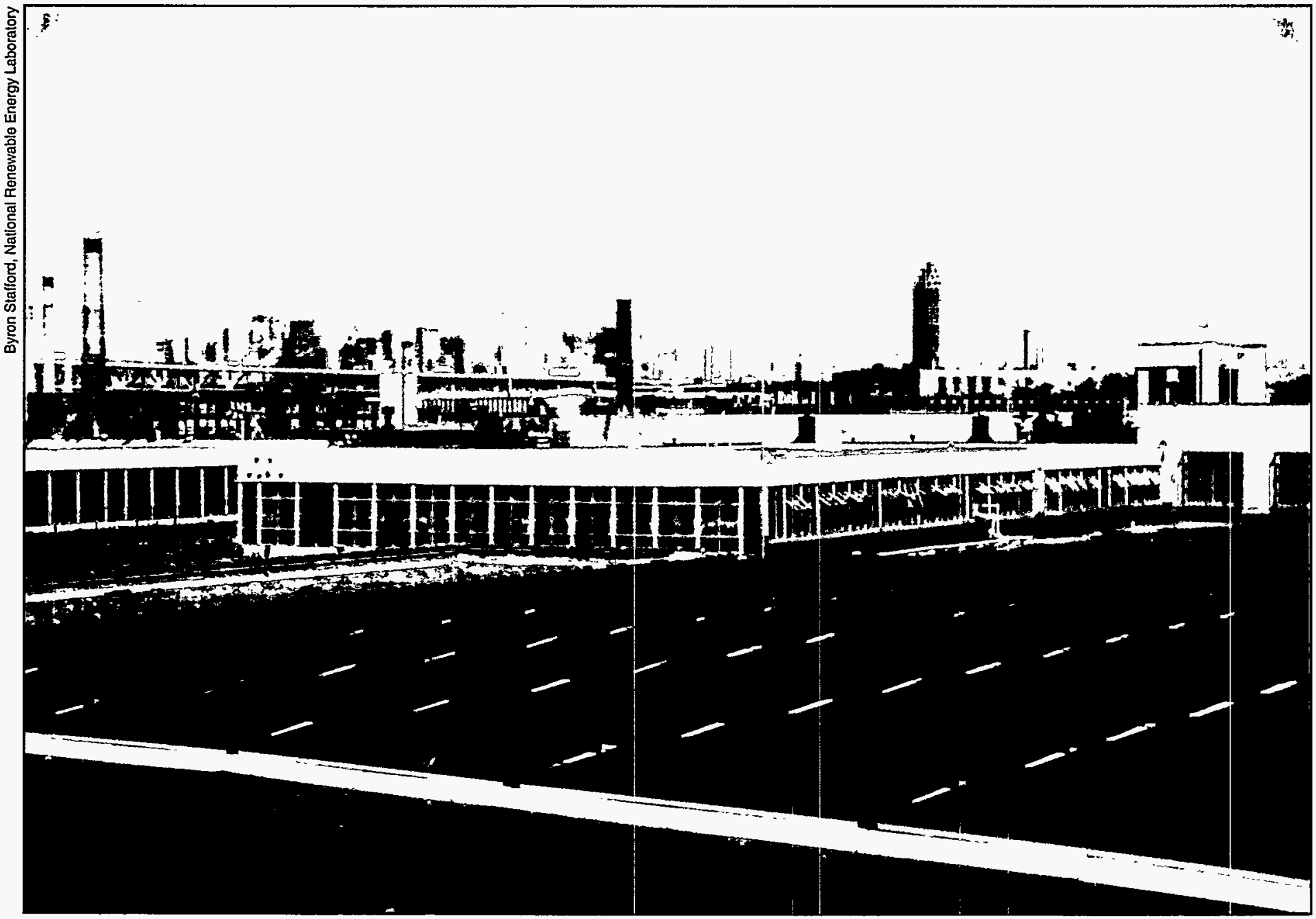

The New York Power Authority is monitoring the performance of this 17-kWa-Si system as part of the PV Program's Amorphous Silicon Utility Industry Project. The system, located on the roof of an office building owned by the New York Transit Authority in Maspeth, New York, provides the power authority with demand-side management. 
offer their analyses to other utilities so they, in turn, can evaluate the benefits of using PV plants to support overloaded substations or other portions of their grids.

PVUSA demonstrates the advantages of joint ventures. Program participants direct activities, share costs and benefits, and thus potentially gain valuable information. Meanwhile, the venture continues even if individual members reduce their participation. PVUSA test sites offer industry a proving ground for emerging PV technologies, utilities hands-on experience, and PV-system suppliers experience in meeting utility specifications.

\section{Building Opportunities in the United States for Photovoltaics}

Buildings consume approximately two-thirds of the electricity generated in the United States. At the same time, there is a lot of space on the roofs and walls of these buildings that could be used for PV generation capacity. Furthermore, utilities increasingly recognize that placing electrical generation close to customers (such as on buildings) reduces their transmission and distribution costs.

PV on buildings can replace conventional windows, skylights, and walls while generating electricity at the same time. However, incorporating PV into building materials is technically complex and involves normally separate parts of the buildings. It also requires joint development among several building-materials industries.
These technical and industrial issues have slowed development of buildingintegrated PV in the United States.

To help U.S. industry enter the fierce international competition for building integrated PV, DOE solicited proposals from teams of organizations to conceptualize and develop PV products for potential use in buildings. Twenty-nine teams proposed concepts, and in FY 1993, five of the teams began work on the planned 5-year, \$25-million (from DOE), cost-shared Building Opportunities in the United States for Photovoltaics program.

Each of the five PV:BONUS teams includes a lead contractor and up to 10 other organizations representing building-materials manufacturers, building contractors, PV suppliers, utilities, colleges and universities, systems designers, architectural and engineering firms, and building owners. The five teams are developing the following PV products.

\section{Dispatchable peak shaving system}

Delmarva Power and Light Co., an electric and gas utility.

Although PV output has been shown to correlate well with the peak demand periods of many utilities, others have peaks that extend beyond sunset.

To address power needs after sunset, Delmarva and its team members are designing a PV system with batteries that can be called upon ("dispatched") by the utility much as power from conventional power plants is managed. The Delmarva team will also perform a detailed market assessment, and 
determine how they should design and sell PV systems within their service territory.

\section{Flexible, lightweight roofing material}

Energy Conversion Devices, Inc. (ECD), a PV module manufacturer.

PV systems that double as electrical generators and roofing material provide extra value to the building owner. ECD, along with the National Association of Homebuilders and others, will develop a flexible, lightweight PV module to be integrated into rooftops. They will also verify the technical and economic performance of the modules, develop a marketing plan, and lay the foundation for highvolume commercialization.

\section{Manufactured homes with PV}

Fully Independent Residential Solar Technology, Inc. (FIRST), a nonprofit organization teamed with a developer and a builder of manufactured homes.

Modular houses that are manufactured in a factory and assembled at the building site are an increasingly popular way to reduce home construction costs. FIRST will build modular, manufactured houses that incorporate PV generating capacity into the design. The houses will also include energy-efficiency measures such as passive solar design and solar hot water heaters.

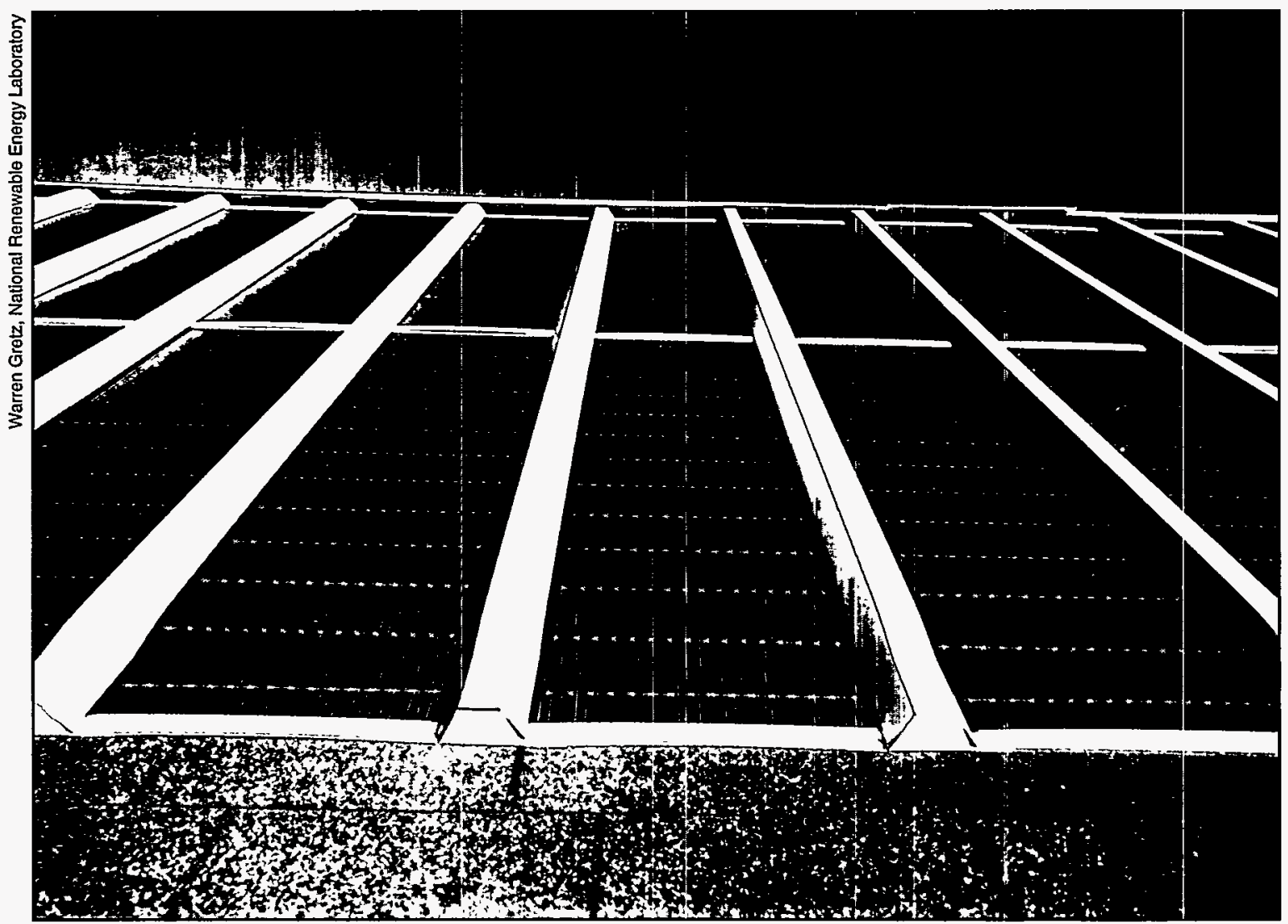

NREL engineers are monitoring the performance of these roof-mounted PV panels that serve a dual purpose. First, they replace conventional building shingles and second, they supply electricity to the building and the utility power grid. 


\section{PV module that produces ac electricity}

Solar Design Associates, Inc., an architectural and systems engineering company.

Today's PV modules produce dc electricity, which must be converted to ac for grid-connected applications. A module producing ac electricity frees architects and designers from dc wiring constraints and inverter sizing issues. Ac modules would also eliminate constraints on orientation and shading.

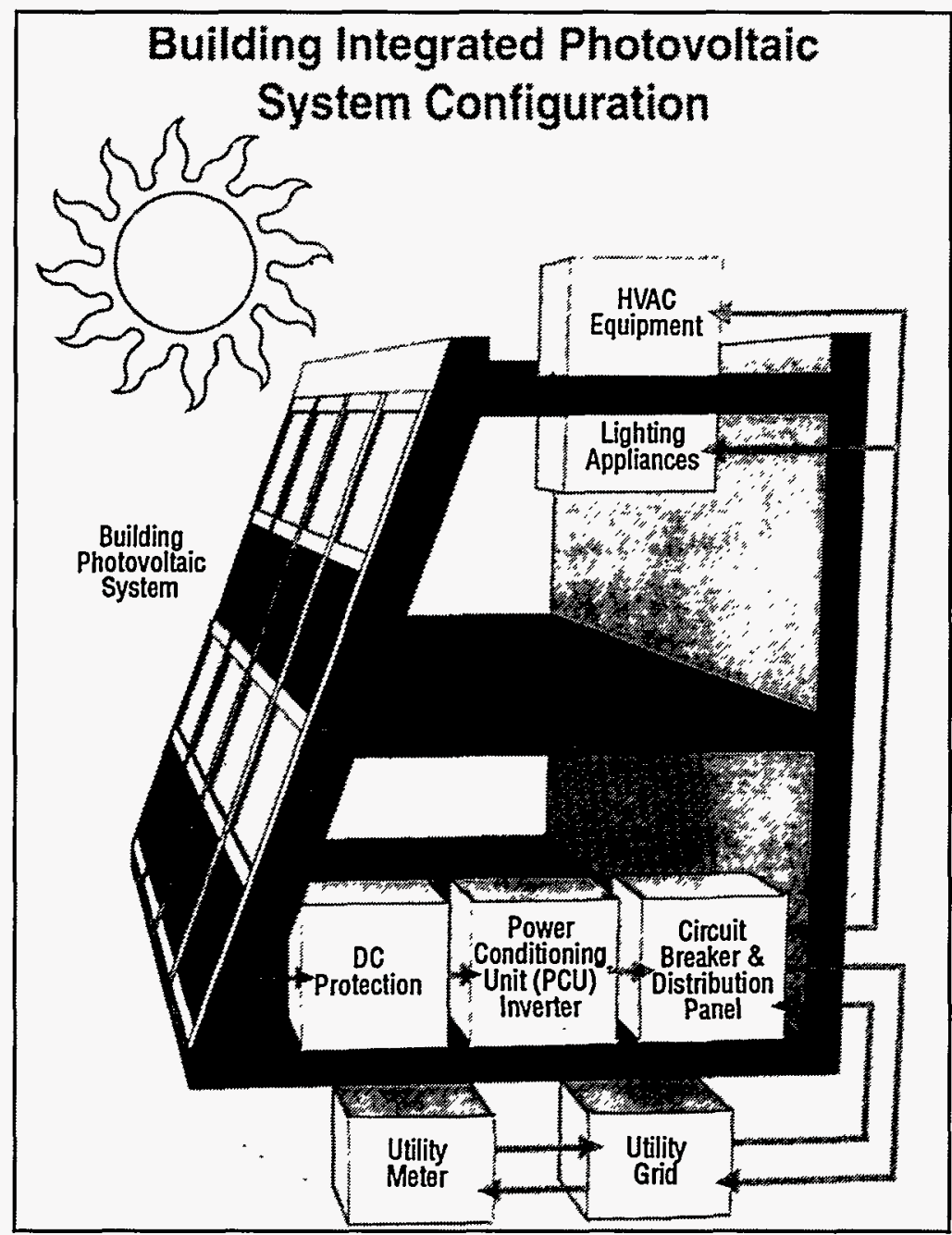

In the future, photovoltaics will be integrated into the structure of buildings. Thus $P V$ will have an architectural function in addition to supplying a portion of the building's electric load.
A team led by Solar Design Associates, Inc., will apply advances in power electronics to include miniature inverters on the back of PV modules. Mass production of inverters and modules in standard sizes should reduce component and installation costs.

\section{Architectural PV glazing system}

Advanced Photovoltaic Systems, Inc., (contract under negotiation), a PV manufacturing company.

Glass is increasingly used for building facades, lighting, and ventilation.

A team led by Advanced Photovoltaic Systems, Inc., is designing a system of matching glazing products which includes PV panels. The products will consist of a combination of opaque, semitransparent, and clear glazing. They will be incorporated into windows, skylights, and panels for vertical and sloped enclosures. The PV glazing can also provide supplemental power for fans and air conditioners.

\section{Additional supporting activities}

In order to increase awareness of PV among architects, the PV Program supports the American Institute of Architects (AIA) in developing a "PV in Buildings" curriculum for architecture students. The course, developed in FY 1993, is being pilot tested and will be distributed in FY 1994 to schools of architecture in North America.

DOE is also supporting AIA in its work to coordinate U.S. participation in a European-sponsored International Architectural Ideas Competition to design buildings that integrate PV. 


\section{Balance of Systems}

As the cost of PV modules continues

to decrease, the cost and performance

of other PV systems' elements, such as

inverters, batteries, and other electrical

equipment, are becoming more important to the industry. Non-module components of PV systems are usually manufactured by larger companies for which PV is a tiny part of their overall business. As such, PV commands little attention from these companies and garners only a small portion of the market, thus far warranting little corporate investment.

\section{SOLTECH}

DOE cosponsors SOLTECH, the major U.S. conference on solar energy, to promote the exchange of information on renewable energy technologies. Over 1400 representatives from industry, government, and various regulatory agencies and market sectors, attended technical sessions and talked with industrial exhibitors at SOLTECH'93 in Washington, D.C.

The SOLTECH conference is held every spring.
Balance-of-system (BOS) components are designed to reduce the cost and increase the reliability of PV systems, thereby making them more marketable. The PV Program funds are being used to develop:

- charge controllers to improve battery lifetimes

- system controllers to improve operating efficiency and power quality through better load control

- switchgear and safety equipment for PV systems

- advanced electronic equipment to reduce the cost of delivered power

- hardware interfaces to allow utilities to access information from users of PV systems at remote locations.

The Program's activities also include $R \& D$ contracts for developing new BOS components. For example, Utility Power Group (UPG) is developing safety switches that incorporate dc disconnect and ground-fault interruption in a compact, weatherproof package.

For the past several years, the PV Program has also been operating facilities to test batteries and charge controllers for stand-alone systems. In FY 1993, the test facilities were upgraded to handle power processing and control systems of up to $150 \mathrm{~kW}$ for hybrid PV/generators and grid-connected applications. 


\section{Standards}

To be accepted in all potential markets, PV systems must conform to accepted national and international standards. Unfortunately, many of these codes do not currently address PV systems directly. PV Program personnel work closely with the standards groups that are revising these codes to ensure appropriate requirements for PV systems. In FY 1993, for example, PV Program personnel worked with the Institute of Electrical and Electronic Engineers (IEEE) to develop the second draft of Recommended Practice for Qualification of PV Modules.

In addition, in FY 1993, PV Program personnel assisted manufacturers of PV modules, systems, and BOS components in applying for and gaining certification from national testing and safety laboratories such as Underwriters Laboratory.

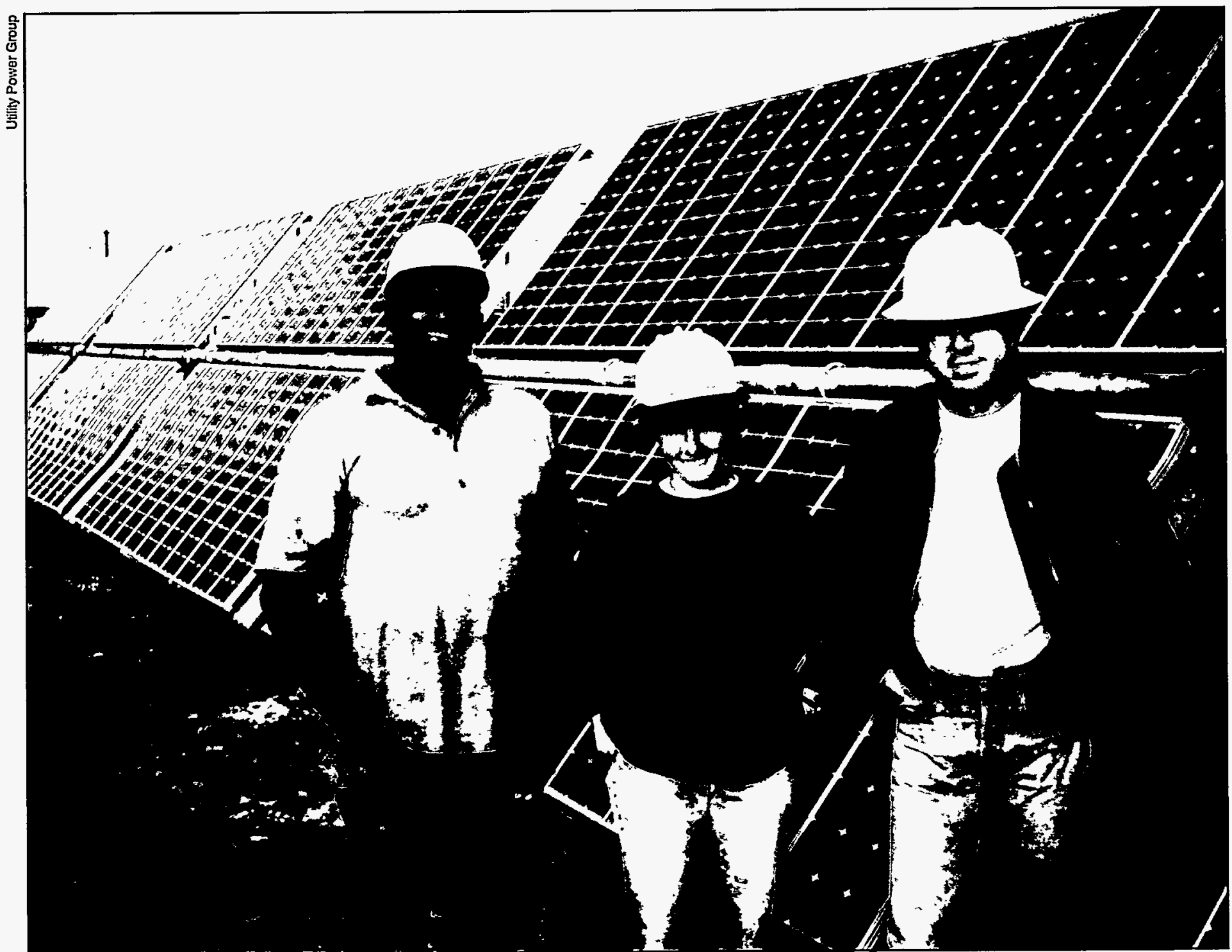

Beth Richards of Sandia National Laboratories works with Utility Power Group employees Tyree Hudson (left) and Rick West (right) to install their 200-kW grid-support system for Sacramento Municipal Utility District. 


\section{Advances in Manufacturing Hasten Availability of Innovations}

In FY 1993, PV manufacturers continued to increase the competitiveness of U.S. products. They do this by reducing manufacturing costs, scaling up processes from the bench scale in a laboratory to the production-line scale in a factory, and developing larger cells and modules. The PV Program shares the cost of this development work with the PV industry and helps U.S. companies develop concepts into products, test hardware, and analyze results.

\section{Photovoltaics}

Manufacturing Technology Project

In FY 1990, DOE and the PV industry joined forces to launch the Photovoltaics Manufacturing Technology (PVMaT) Project. PVMat is a 5-year, cost-shared manufacturing development project that will mobilize more than $\$ 100$ million-\$55 million from DOE and a nearly equal amount from industry-to reduce manufacturing costs, improve quality, and increase U.S. industrial capacity for producing PV components and systems.

\section{Industry Announces Increases in Production Capacity}

Advanced Photovoltaic Systems, Inc, is nearing completion of its 10-MW-per-year amorphous silicon production facility in Fairfield, California.
United Solar Systems Corporation (USSC) will begin construction of a 10-MW-per-year plant in Newport News, Virginia. This will be the world's largest manufacturing plant of a-Si alloy $P V$ modules.

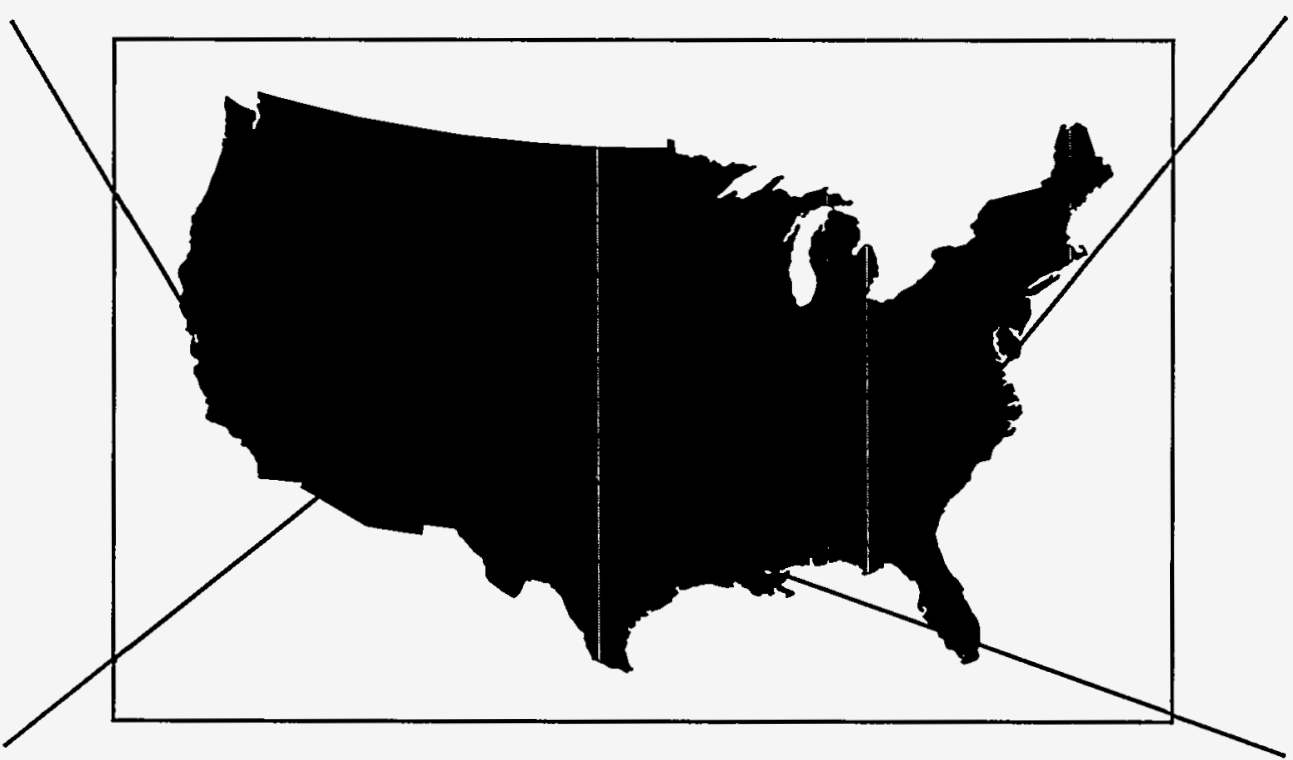

Golden Photon, Inc., continued construction of a 2,800-m² (30,000- $\left.\mathrm{ft}^{2}\right)$ plant in Golden, Colorado. Golden Photon will use this plant, which has a production capacity of $2 M W$ per year, to produce cadmium telluride (CdTe) thin-film modules.
Texas Instruments (TI) plans a factory in Texas to produce up to $15 \mathrm{MW}$ per year of its modules using the spherical cell technology it developed with Southern California Edison. 


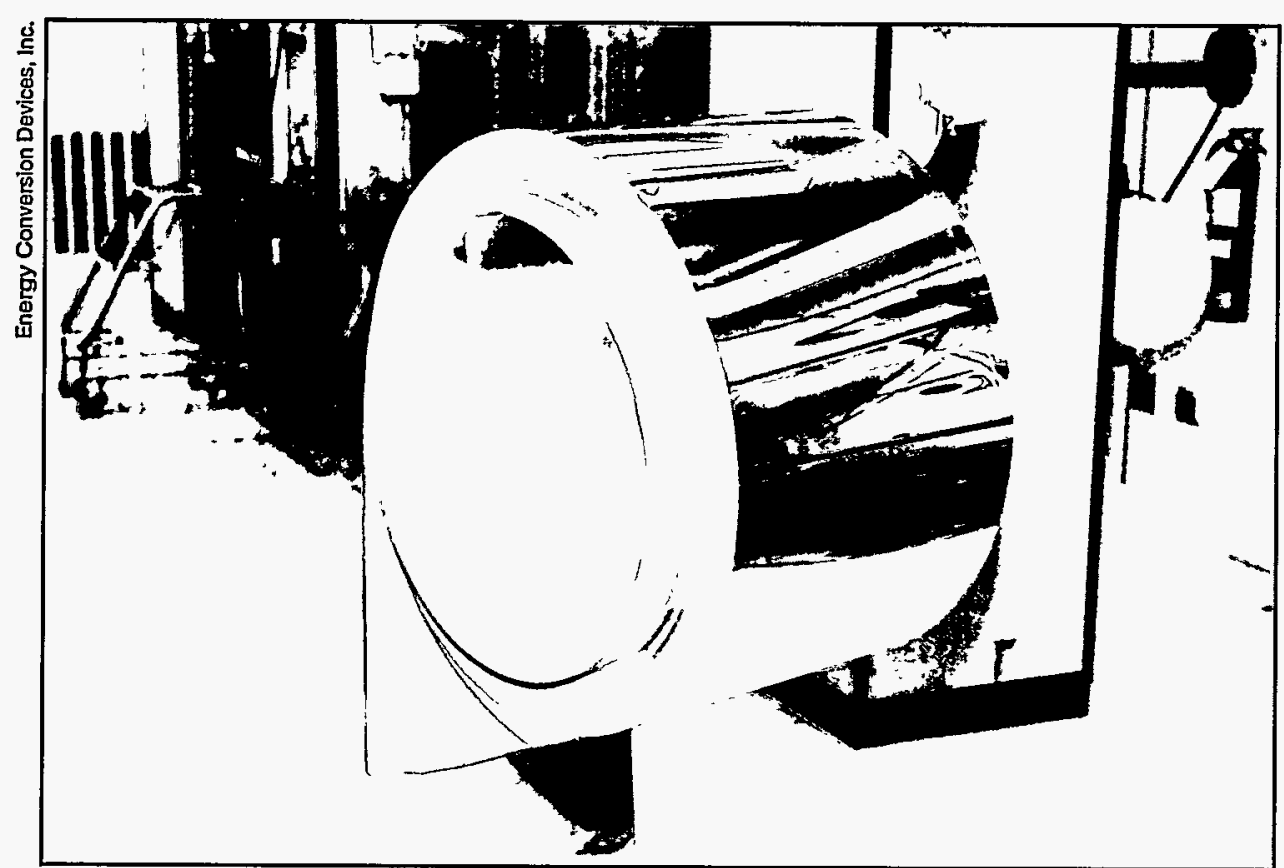

Energy Conversion Devices, Inc., can maintain very high product quality (uniformity varies less than 0.1\%) and cell yield (greater than 99\%) on its new continuous-processing production line. This flexible roll of a-Si cells will produce modules with a rating of $20 \mathrm{~kW}$.

The PVMaT project is made up of three procurement phases that address separate $R \& D$ requirements.

In Phase 1 (completed in FY 1991), 22 PV companies identified

In addition to increasing capacity and improving product quality, each of the PVMaT contracts stresses the development of environmentally sound manufacturing techniques while assuring worker safety and health.
Phase 2A: Improving Processes

Projects in Phase 2A of PVMaT focused in FY 1993 on two concerns of manufacturers-continuous processing of materials and making larger-area cells and modules. Production lines with continuous processing of materials can increase factory output by reducing delays and improve product uniformity by increasing control of the environmental conditions in which the cells and modules are produced. PV cells and modules are produced from exact quantities of semiconductor materials whose chemical purity and crystalline structure must meet strict specifications. Sometimes the processing of these materials takes place at elevated temperatures or low pressures, or both. Continuous processing allows the manufacturer to exert more exact control over this processing environment. Producing larger cells and modules means fewer interconnections, fewer grid lines to produce shading, fewer processing steps, reduced costs for materials and labor, and more electrical output from the cells and modules.

In FY 1993, Energy Conversion Devices designed and built a continuousprocessing PV manufacturing facility that makes large-area cells and modules. The facility produces up to $2 \mathrm{MW}$ of a-Si alloy modules per year. The continuous roll-to-roll process applies nine layers of semiconductor material in a single pass onto a $760-\mathrm{m}$ (2500-ft)-long, 35-cm (14-in)-wide roll of flexible stainless steel. The resulting multi-junction solar-cell material is then cut into $0.37-\mathrm{m}^{2}\left(4-\mathrm{ft}^{2}\right)$ modules. 


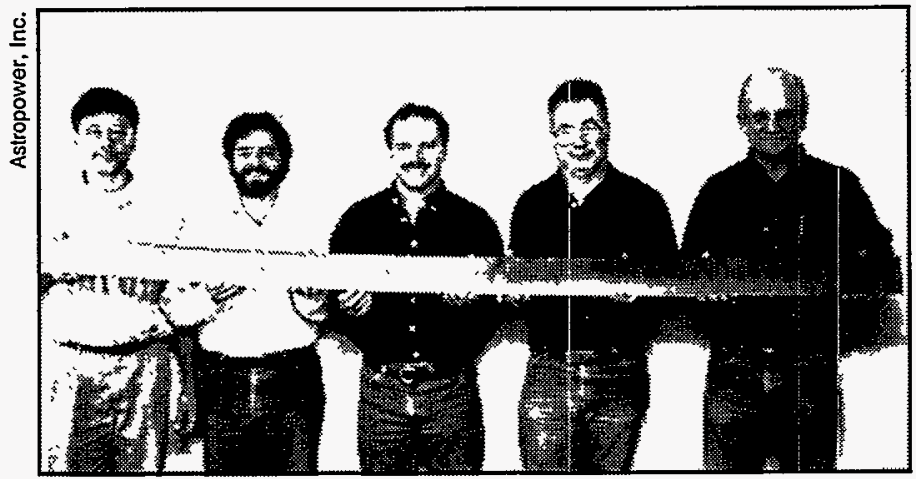

Continuous polycrystalline silicon sheets require no sawing or polishing before being made into large area (15-cm wide) solar cells. Astropower produces these sheets in a new machine with a production capacity of $1.7 M W$ per year.

Another manufacturer, Solarex Corporation, is scaling up production of multi-junction, large-area a-Si modules under PVMaT. In FY 1993, Solarex improved the deposition system, developed a new laser-scribing system, and installed module fabrication machinery. These changes increased processing control and reduced material costs.

Tracking the costs of each processing step helped two other manufacturers, Utility Power Group and Advanced Photovoltaic Systems Inc., improve their production efficiencies. In FY 1993 these companies reduced module termination and encapsulation costs by $50 \%$, thus reducing overall production costs by $30 \%$.

Through PVMaT, the PV Program helped one of the largest producers of PV modules, Siemens Solar Industries, Inc., increase production and reduce costs in FY 1993. Siemens, which produces half of the PV modules made in the United States, increased its capacity to produce silicon wafers used in crystalline silicon (c-Si) cells more than $30 \%$.
Siemens made these advances by producing thinner wafers and improving the process for sawing bulk crystalline silicon into wafers. Siemens also saved $\$ 300,000$ per year in replacement parts by switching to components with tighter tolerances in their crystal growers. During the first year of its PVMaT contract in FY 1993, Siemens reduced its overall manufacturing costs by $11 \%$. ENTECH, Inc., produces concentrator PV modules that focus sunlight onto small, highly efficient solar cells. Concentrator systems contain more parts than flat-plate systems, but they produce more electricity per given area of solar-cell material. Under PVMaT and the PV Program's Concentrator Initiative, ENTECH has lowered the production costs of many components. For example, lens costs are down $90 \%$, prism covers $75 \%$, and cell interconnects $80 \%$. In addition, ENTECH is working with Sandia on improving its array-tracking system.

\section{Phase 3A: Exploring Generic Issues with Teams}

PVMaT's Phase 3A projects begun in FY 1993 are addressing issues common to the PV industry as a whole, such as increased automation and longer system lifetime.

For example, Spire Corporation leads a team of researchers that will investigate how to increase the processing rate, control, yield, and efficiency of material with a thickness of less than 200 microns $\left(10^{-6} \mathrm{~m}\right)$.

PVMaT is also addressing generic issues affecting the lifetime of PV 
systems that have surfaced now that some PV systems have been operating in the field for more than 15 years. One of these issues is the long-term effect of sunlight on encapsulants, which are used to seal PV modules. Discoloration of encapsulants has been reported in some systems. Springborn Laboratories will lead a team of researchers to evaluate the effect of discoloration on the

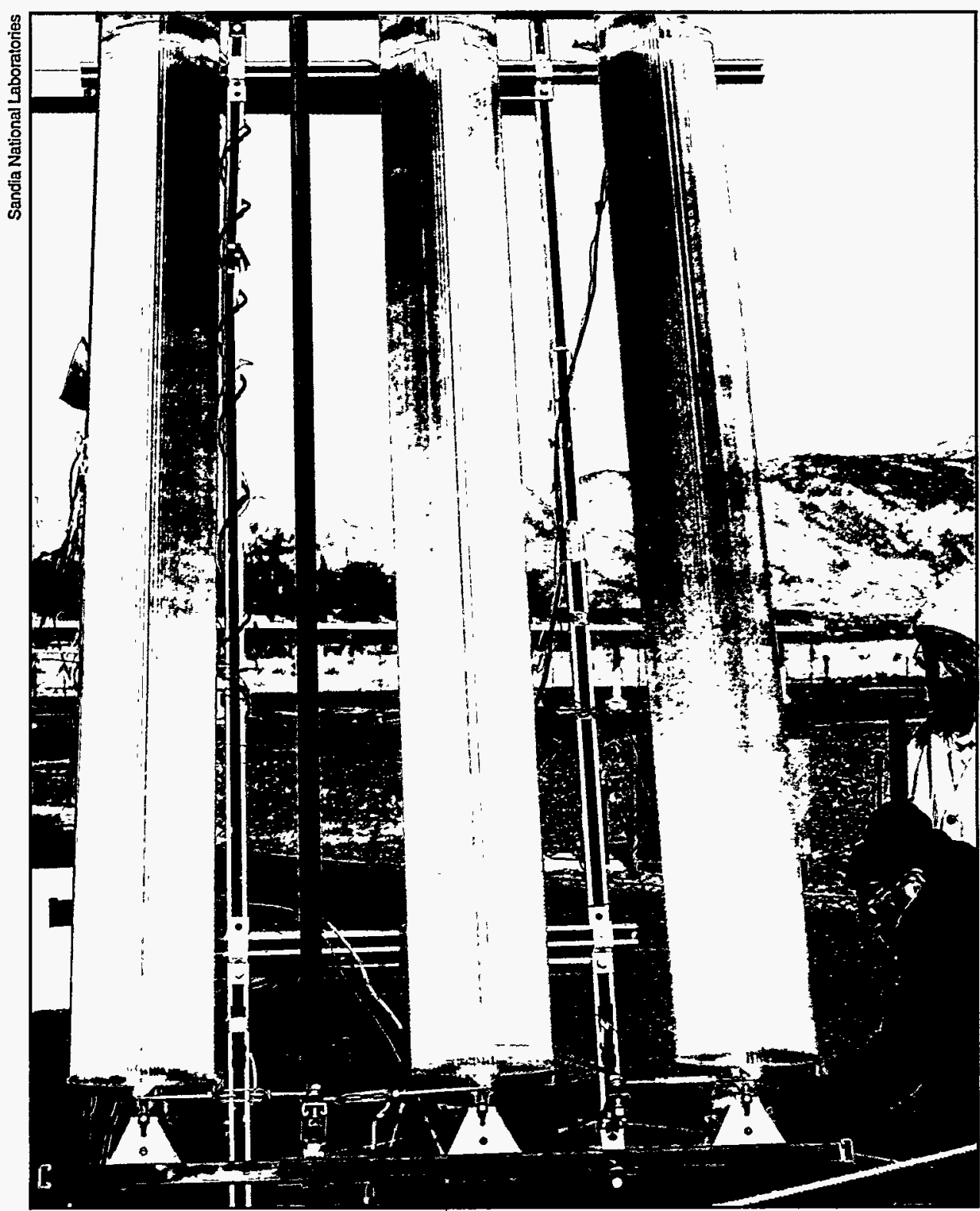

Solar Engineering Application (SEA) Corporation concentrator modules undergo qualification testing at Sandia. performance of existing systems and eventually develop alternative encapsulants, once discoloration mechanisms are understood.

\section{Other Developments in Manufacturing}

When a company attempts to adapt new techniques for fabricating PV cells and modules it developed in a laboratory to commercial production lines, the PV Program's test facilities help ensure that product quality is maintained. Performance testing also helps industry verify its efficiency measurements and calibrate its instruments correctly. Several companies took advantage of these services in FY 1993.

Golden Photon, Inc., is preparing to build its 2-MW plant to produce PV modules made from cadmium telluride (CdTe). The company will soon submit its prototype modules to undergo the PV Program's Interim Qualification Tests and Procedures to demonstrate durability. Manufactured products will also need to pass these tests. Solar Cells, Inc., also used PV Program outdoor test results and the Interim Qualification Test protocol to evaluate methods of encapsulating cdTe thin-film modules.

Spectrolab, making only minor modifications to its production line of PV cells used in outer-space applications, produced $18 \%$-efficient silicon cells for terrestrial concentrating PV systems. PV Program personnel verified the cells' performance at one of their test laboratories. 
Texas Instruments is developing a flexible PV cell composed of c-Si spheres on an aluminum backing. Using low-cost materials such as metallurgical-grade silicon and aluminum foil, TI expects its modules to be much less expensive than those available commercially today. TI scientists used PV Program laboratories to explore the properties of their metallurgical-grade silicon.

Crystal Systems is cutting manufacturing costs by employing reusable ceramic crucibles. A major cost of growing silicon ingots to make solar cells is the quartz crucibles that are consumed in the process. The Program's Photovoltaics Device Fabrication Laboratory (PDFL), located at Sandia, tested materials produced in reusable crucibles for impurities and defects to help Crystal Systems perfect its process. So far the Crystal Systems' material has performed well in PV cells. Using this new process, the company has produced single ingots weighing $100 \mathrm{~kg}(220 \mathrm{lb})$.

\section{Module Testing and Evaluation}

Both NREL and Sandia have extensive testing and evaluation facilities to support PV industrial manufacturing and system development. In FY 1993, for example, NREL tested advanced thinfilm technologies for Siemens Solar Industries, Inc., Solar Cells, Inc., and United Solar Systems Corporation at its grid-connected outdoor test facility in Golden, Colorado. Sandia worked with developers of concentration and flat-plate technologies at its outdoor test site in Albuquerque, New Mexico. Tests at PV Program laboratories are conducted under systems and manufacturing development contracts, and under cooperative agreements with industry. NREL can perform all the tests for the Interim Qualification Tests and Procedures for flat-plate modules, which are frequently used by customers to qualify bidders on PV contracts. Sandia has the specialized capability to test concentrating PV systems as well as flat-plate collectors.

In FY 1993, PV Program engineers teamed up with the Southwest Regional Experiment Station in Las Cruces, New Mexico, to study lifetime issues for 8- to 12-year-old modules from installations worldwide. Together with module manufacturers, researchers performed "post mortem" analyses of old modules. The resulting information on chemical and physical changes in modules over time will help industry improve manufacturing materials and processes.

The PV Program also sponsors PV Module Performance and Reliability Workshops to help industry assimilate test results bringing manufacturers and researchers together to report on performance issues. In FY 1993, about 150 researchers from industry, universities, and laboratories met to discuss reliability and performance issues. 


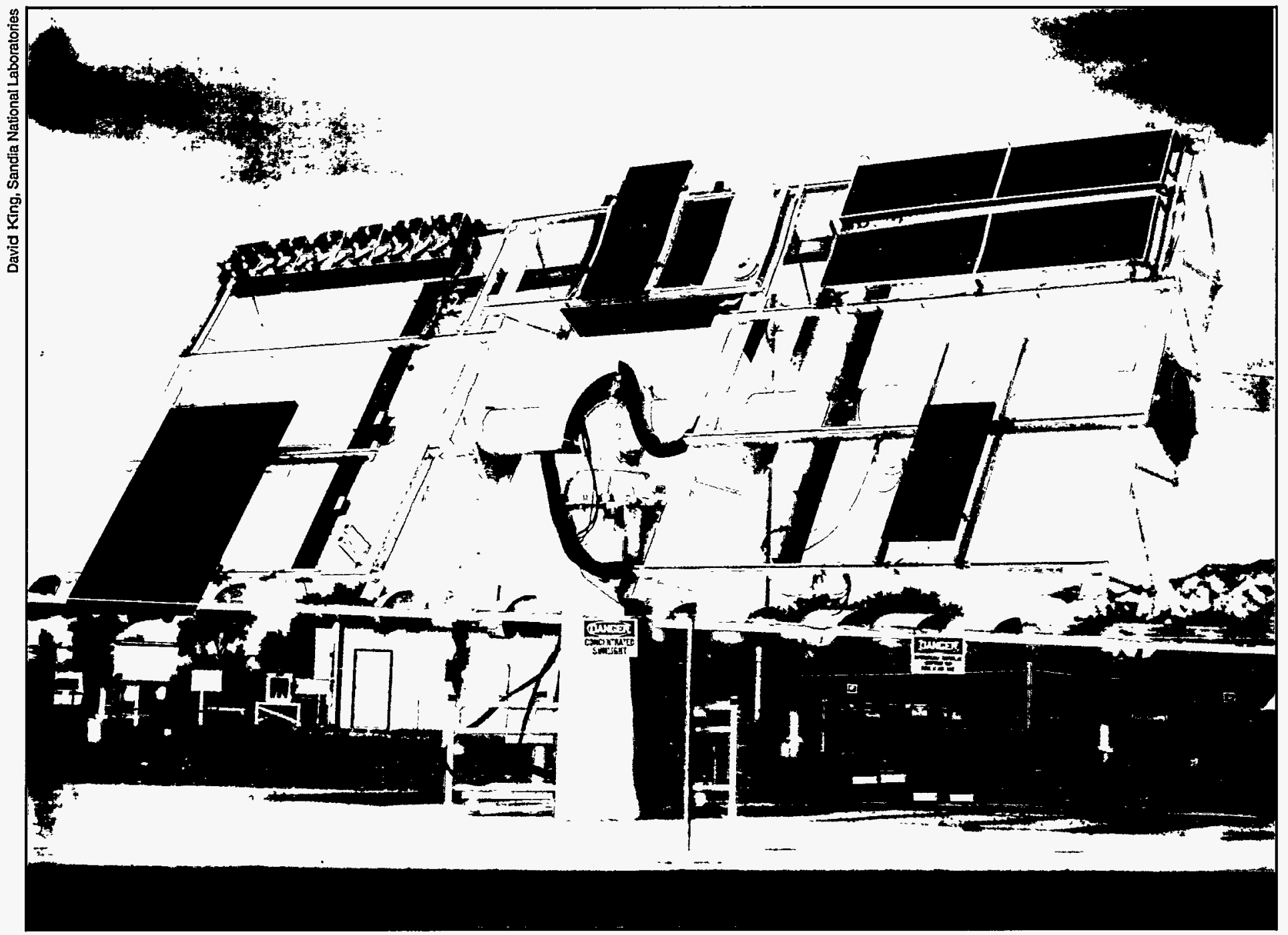

This new solar tracker and data collection system at Sandia makes outdoor performance measurements as precise as those generated by indoor solar simulators. Testing modules outdoors is the only way to relate performance to environmental variables such as solar insolation, wind speed, and air temperature. 


\section{Environment, Safety, and Health}

To reduce the environmental impact of producing PV cells and modules, the PV Program encourages laboratories and contractors to practice safe handling procedures, reduce the amount of toxic chemicals used, and recycle cell and module materials. For example, the PDFL reduced its chemical use in FY 1993 by over 30\%, saving $\$ 13,000$ in hazardous waste disposal costs.

Semiconductors and computer chips are often cleaned with ozone-depleting freon. Siemens Solar Industries, Inc., eliminated the use of freon in FY 1993 by finding a solder paste for module production that does not require cleaning. Siemens was also able to reduce the volume of caustic waste it produces by $45,480 \mathrm{~L}$ (12,000 gal) per year by cutting grid lines on the chips with a saw instead of etching with chemicals.

Golden Photon, Inc., instituted what it called a "cradle-to-cradle" recycling program for cadmium, a toxic component of its CdTe thin-film modules, in FY 1993. Golden Photon will guarantee a return value for all modules at the end of their useful life. The company will then recycle the cadmium, using it to make new modules.

The PV Program also provides support to Brookhaven National Laboratory to explore critical environmental, health, and safety issues raised by researching and manufacturing PV materials. In FY 1993, Brookhaven researchers, in collaboration with the
National Institute of Health, studied the toxicity of copper indium diselenide (CIS) and cadmium telluride. Both PV materials are used in thin-film modules. Preliminary results from the study indicate that, although the two chemicals are toxic in their original form, they are nontoxic when processed and incorporated into PV devices and modules. Once processed, the two materials are not absorbed into the human body (i.e., they are not "biologically accessible") because they do not dissolve in water. Brookhaven will publish the final report in FY 1994. 


\section{Cooperative Research Improves PV Technology}

The year's progress in photovoltaics is based on a better understanding of the fundamental mechanisms controlling the formation and performance of PV materials. New efficiency records, improved manufacturing techniques transferred to industry, inventions serving the research community, and incremental increases in our understanding of PV science are all outcomes of the PV Program's cooperative research on PV technology.

\section{Crystalline Silicon}

About $72 \%$ of today's commercially available PV modules are made from crystalline silicon cells. Because the majority of PV companies have already tooled to manufacture c-Si products, many of them can quickly utilize scientific innovations in materials and devices from c-Si laboratory research.

Single-Crystal Silicon-higher efficiencies, thinner wafers, and lower-cost materials

The quality of the silicon used to make c-Si cells has a considerable impact on the efficiency and cost of the cells. Today's commercial c-Si cells, which typically have efficiencies of $15 \%$ to $16 \%$, are made from expensive, high-quality, single-crystal silicon. The purest $(99.99999 \%)$ and most expensive is called float-zone silicon; it makes the best, most efficient c-Si cells.

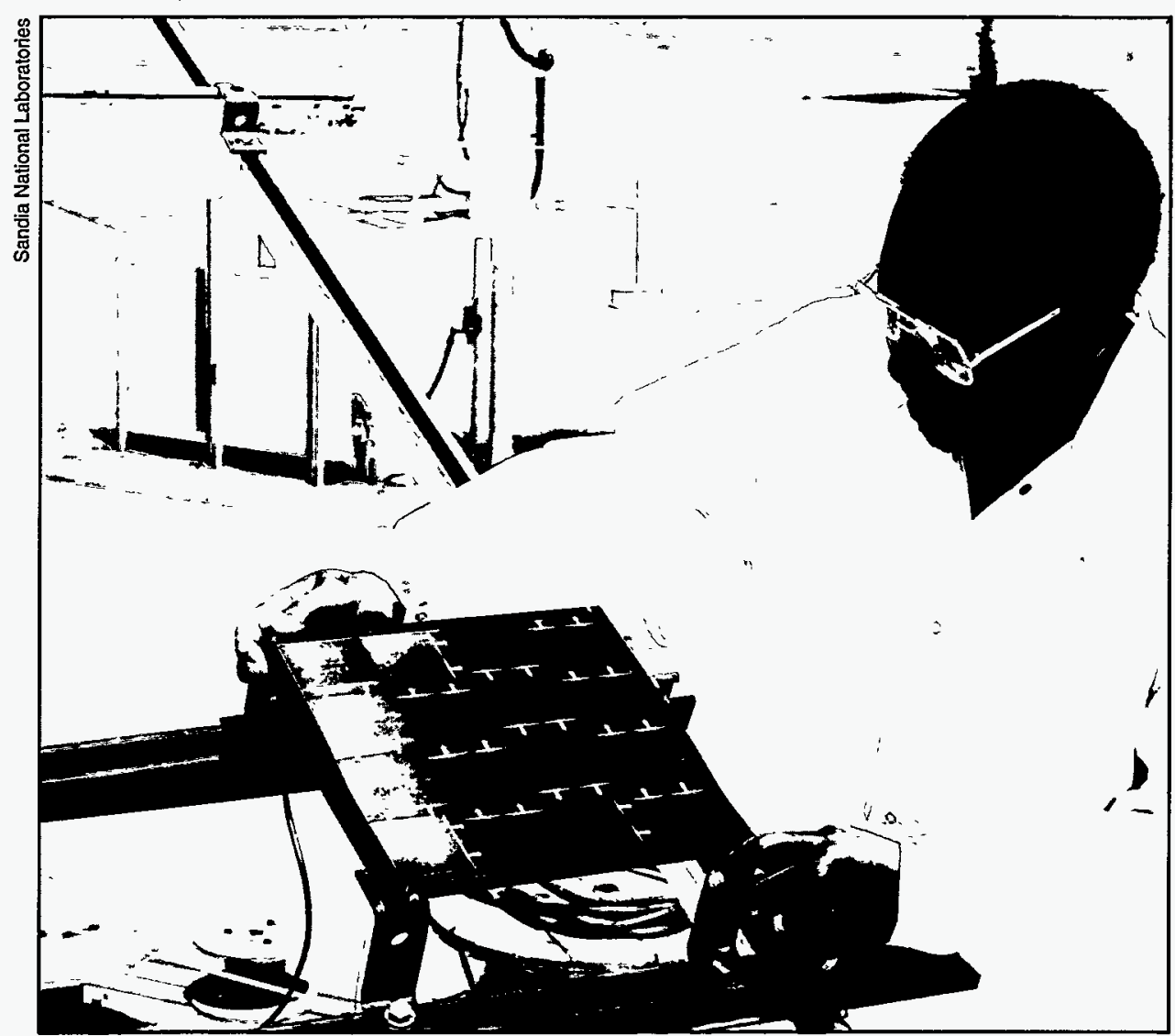

This c-Si module, produced by the University of New South Wales, achieved an aperture-area efficiency of $20.5 \%$, the most efficient flat-plate module made to date. 
PV Program and industry scientists are seeking ways to use lower-grade silicon to reduce the cost of PV cells. For example, scientists from Siemens Solar Industries, working with the PV Program's PDFL at Sandia, produced a c-Si cell in FY 1993 with a record efficiency of $20 \%$ (at 40 suns) using "solar grade" Czochralski (Cz) silicon. $\mathrm{Cz}$ silicon is not as pure as float-zone silicon because of the way it is produced, but it can be made into cells for one-fifth the cost.

Researchers at the PDFL made a $23 \%$-efficient (at 40-80 suns) concentrator cell in FY 1993 from float-zone silicon using a process that may allow the use of lower-grade, cheaper silicon. They produced the cell using a single high-temperature-furnace (above $800^{\circ} \mathrm{C}$ ) process, and by reducing the number of labor-intensive steps by $40 \%$.

Another way to reduce costs is to make PV cells thinner. In FY 1993, Siemens began making its silicon wafers (used to make c-Si cells) thinner to reduce the amount of high-grade silicon used in a cell.

\section{Multicrystalline Silicon-improving cell efficiency, material uniformity, and analytic techniques}

Multicrystalline (or polycrystalline) silicon materials are composed of very small crystals that bond together to form a single material. Multicrystalline cells have lower efficiencies than single-crystal silicon cells; however, they are less expensive, which makes them popular in the marketplace. Multicrystalline silicon currently accounts for almost $35 \%$ of the world PV market, compared with about $37 \%$ for single-crystal silicon.

The PV Program initiated the Multicrystalline Silicon Research Cooperative in FY 1993 to coordinate research on issues that are beyond the capabilities of any one company or laboratory. Under the research cooperative, scientists from industry and government laboratories meet quarterly to discuss cell design, manufacturing, and product development issues common to members of the cooperative, which include Astropower, Crystal Systems, Solarex, Texas Instruments, NREL, and Sandia. Industrial members provide material samples (at least 50 wafers each) to the laboratories for testing. The samples are then subjected to experimental processes and evaluated according to their response and potential to improve cell performance.

Several members of the cooperative conducted a multi-factor experiment in FY 1993 to study phosphorus and aluminum gettering. Gettering is a process by which impurities, which reduce performance, are removed from the cell surface after a heat treatment. The Georgia Institute of Technology produced a multicrystalline silicon cell in FY 1993 with a record efficiency of $17.6 \%$ after removing impurities using aluminum alloy and phosphorous gettering.

Another approach is to use hydrogen passivation (carried out by diffusing hydrogen into the silicon) to nullify the negative effects of impurities in the crystalline structure of the silicon. 
The PV Program helps the PV industry lower costs and increase the performance of thin films so the products can compete in energy-production markets on a global scale.
NREL is working with bulk hydrogen passivation to improve the performance of multicrystalline silicon.

Finally, the PV Program brings researchers from all over the world together to discuss their work on improving the performance of silicon. The annual Workshop on the Role of Point Defects and Defect Complexes in Silicon provides a forum for discussing gettering, impurity and defect passivation, and defect engineering.

\section{Thin Films}

The PV Program has explored thin-film photovoltaic materials for 2 decades because of the promise of significantly lower manufacturing costs. To construct thin-film PV modules, very thin layers of semiconductor material are applied to a low-cost backing such as glass or aluminum foil. Thin films demand less semiconductor material per device; thus, the cost of materials is lower. In addition, thin-film manufacturers can take advantage of existing industrial processes such as those used to manufacture and coat glass, processes that are well established and relatively inexpensive.

The challenge facing developers of thin-film technologies is twofold:

1. to build prototype modules that meet ambitious performance and reliability goals; and

2. to develop materials and processes yielding higher efficiencies, greater product uniformity, and lower costs.
To help meet these challenges, the PV program maintains research contracts with most of the companies in the U.S. thin-film industry. These contracts are with companies developing two new polycrystalline thin-film materialscopper indium diselenide and cadmium telluride-and with companies working to improve the efficiency of amorphous silicon.

\section{CIS-record-breaking technique transferred to industry}

The PV Program works with several industrial partners to move CIS modules into commercial production. In FY 1992, NREL scientists added the element gallium to CIS (CIGS) and boosted laboratory cell efficiencies to 13.7\%. In FY 1993, several companies manufactured prototype modules from CIGS using this technique.

In FY 1993, NREL researchers produced CIGS cells in a laboratory with a record efficiency of $15.5 \%$. The researchers attempted to overcome two of the most serious barriers to manufacturing prototypes of CIGS cells in the way they produced the cells. Applying their understanding of reaction pathways between alloys, the researchers improved the (area) uniformity of the films and and their adhesion to the substrate. They also optimized processing temperatures using a deposition process that can be scaled up for making larger cells. The NREL researchers made detailed technical presentations in FY 1993 to U.S. companies developing CIS. Today, five industrial teams, working in collaboration with PV Program 


\section{PV Program Laboratories Develop Unique Equipment}

Two new devices produced at NREL and Sandia in FY 1993 increase the accuracy and speed of cell measurements. Accurate measurements help industry improve its production processes and products.

\section{Scanning Defect Mapping System}

NREL scientists received the prestigious R\&D 100 Award in FY 1993 for developing the Scanning Defect Mapping System (SDMS). The award is given by $R \& D$ magazine to the 100 most technologically significant products of the year. The SDMS can quickly characterize commercial silicon samples.

Using traditional methods of characterizing silicon samples is labor intensive and time consuming. Formerly, scientists could only characterize a few samples per week using techniques such as taking optical cross sections of the material and counting dislocations. With the SDMS, mapping defects in a commercial sample $10 \mathrm{~cm} \times 10 \mathrm{~cm}$ ( 1.5 in $\times 1.5 \mathrm{in}$ ) takes only about 2 hours. Furthermore, the printout of the results is much more useful. For example, the system can count dislocations (resulting from etch pits) or can generate maps of grain boundaries in the material.

The SDMS can help scientists in industry laboratories determine the quality of their material, identify mechanisms of defect generation, and shed light on the effect of thermal stresses on the silicon during crystal growth. Thus, the SDMS can be used to improve the design and processing of solar cells.

\section{Spectral-Response Laser-Scanning System}

Scientists at Sandia developed a Spectral-Response Laser-Scanning System in FY 1993 in order to improve the speed and accuracy of their measurements. Accurately measuring spectral response allows better calibration of reference solar cells, which are then used to check the accuracy of other measurements. Spectral response also provides information on the internal electrical and optical behavior of cells.

The laser-scanning system measures spectral response using light generated either from a quartz-tungsten-halogen lamp with a monochrometer or from four separate lasers. In addition to measuring very accurately (with an uncertainty of 1\%), the device can measure the spectral response of a cell to 50 different wavelengths of light in about 8 minutes.

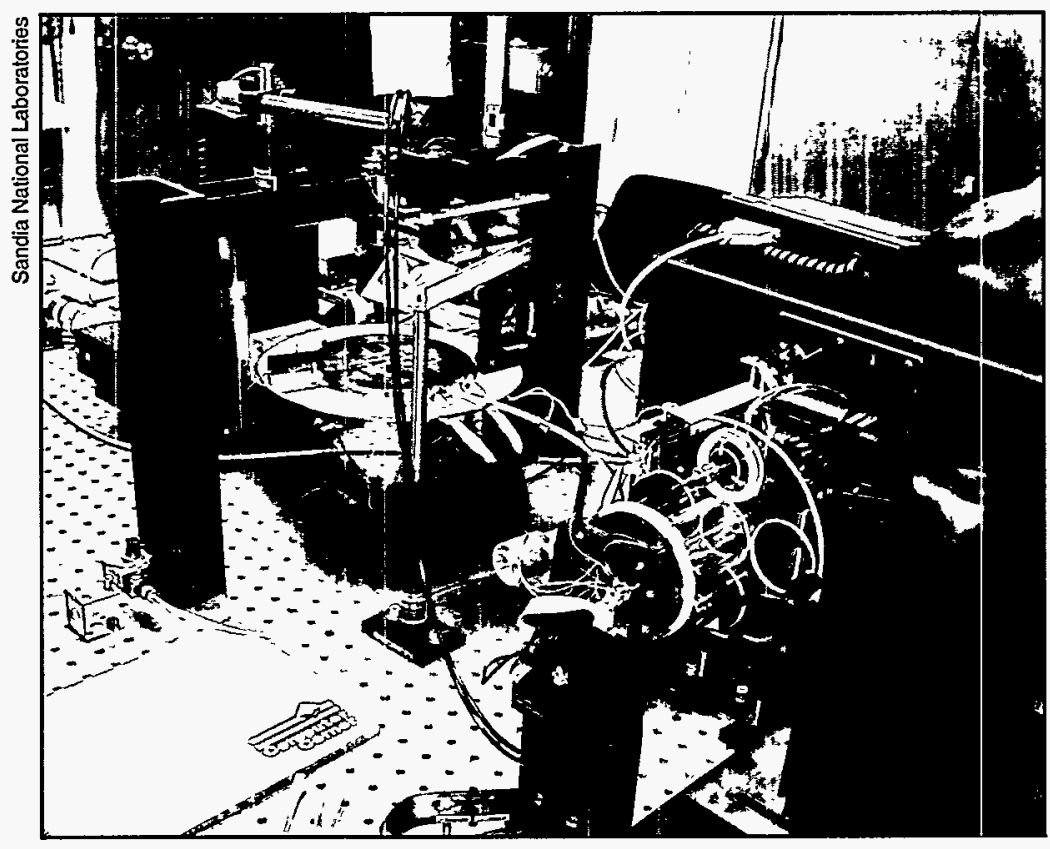

Sandia researchers developed this Spectral-Response Laser-Scanning System in FY 1993 to quickly and accurately measure the electrical and optical response of $P V$ cells to different light spectra. 
scientists, are applying this new

knowledge about reaction pathways

to their proprietary processes.

\section{CdTe-new record and stable performance}

Researchers at the University of South

Florida continued in FY 1993 to improve the efficiency of laboratory cells made with CdTe thin films. In work supported by the PV Program, they produced cells with a record efficiency of $15.8 \%$, the highest efficiency yet recorded for any thin film. Since FY 1992, NREL has been testing similar CdTe cells made at the University of South Florida that have shown no deterioration in performance.

Two U.S. companies, Golden Photon, Inc., and Solar Cells, Inc., made important steps toward commercializing CdTe technology in FY 1993. Both companies produced prototype modules with efficiencies of almost $8 \%$, and both announced plans to build manufacturing facilities in FY 1994. DOE will provide access to laboratory equipment and scientific expertise for these two companies during this critical pre-commercial development phase.

\section{Amorphous Silicon-higher stabilized efficiencies}

The PV Program is working with U.S. companies producing a-Si modules to help them maintain their leadership position in today's market. And by helping these companies increase the stabilized efficiency of a-Si products, the program can assist them in moving into larger-scale markets.
In FY 1993, United Solar Systems Corporation reported a record stabilized efficiency of $11.2 \%$ for a smallarea, dual-band-gap, double-junction a-Si cell. A double-junction a-Si cell is constructed in layers (that form junctions), each of which absorbs a different portion of the solar spectrum more efficiently than a single layer can. In addition, USSC's $1000-\mathrm{cm}^{2}\left(1-\mathrm{ft}^{2}\right)$ prototype a-Si modules demonstrated stable efficiencies of $9.5 \%$.

The PV Program established four amorphous silicon research teams in FY 1993 consisting of researchers from industry, universities, and NREL.

The teams address issues affecting the competitiveness of today's a-Si products. For example, they are attempting to fabricate more efficient cells to reduce or eliminate light-induced reduction in efficiencies (instability), to improve the performance of prototype modules, and to develop higher yield, lower-cost production processes.

\section{High-Efficiency Modules and Cells}

PV Program managers believe that technologies currently under development in the laboratory can meet the program's long-term goals of producing PV modules with an efficiency of $25 \%$. Some of the most promising technologies use elements from groups III and $\mathrm{V}$ on the periodic table.

\section{III-V-alloy high-efficiency cells group breaks records}

In FY 1993, NREL researchers produced a monolithic, multi-junction solar 


In FY 1993, NREL,
Sandia, and industry
laboratories compared
the calibration of their
measurement
equipment through
analysis of various
PV cells and modules.
The results show
improved measurement
techniques and
increased consistency
of measurements within
the PV community.

In FY 1993, NREL, laboratories compared the calibration of their nent through analysis of various PV cells and modules. The results show mproved measurement techniques and increased consistency the PV community. cell made from gallium indium phosphide/gallium arsenide (GaInP/GaAs) III-V materials with a record efficiency of $29.5 \%$. To produce the cell, the researchers carried out a detailed study of "doping" - the interdiffusion of small amounts of an element into a material to affect its material and electronic properties. In this case, the researchers used silicon as a dopant to the III-V materials, a step which produced the record efficiency.

In a related project, the group demonstrated a $25.3 \%$-efficient, single-junction GaAs device. Researchers continue to improve device architecture by collaborating with industry and university researchers.

\section{New Ideas}

The PV Program funded three new contracts in FY 1993 under a project called New Ideas. The three contracts are: Princeton University: Very-HighEfficiency PV Cells Based on Fully Organic Quantum Wells; State University of New York at Buffalo: Thin-Film Silicon by Constitutional Supercooling for Terrestrial Solar Cells; and Spire Corporation: High-Performance Porous Silicon Solar Cell Development. The three contractors will explore untried ideas and fresh approaches to laboratory problems that may have a high payoff. For example, they may generate the next record-breaking cells or develop new materials for use in PV technologies.

\section{Continuing Innovation}

\section{Universities-laboratories, research, and education}

Universities are an important resource for the PV Program. Their laboratories represent a large capital investment, and their researchers have experience in characterizing materials, developing new cells, and transferring technology to industry.

In FY 1994, the PV Program will increase funding for and collaborations with a select group of universities on a number of projects including research contracts, internships, and the inclusion of PV topics in science, engineering, and business curricula. The purpose of these projects is to increase the involvement of minority students in PV research, and to ultimately attract minority scientists and engineers to the growing PV industry. In addition, universities will supply the next generation of researchers and technicians for the PV industry. For example, the Georgia Institute of Technology, with support from the PV Program, is building its own silicon solar-cell "foundry." Faculty and students from the Institute, as well as from other universities, will use the laboratory to do research on silicon PV technologies. 


\section{Additional Achievements in Cooperative R\&D}

\section{Who}

Applied Solar

Energy Corporation

Energy Photovoltaics

Golden Photon, Inc.

International Solar

Electric Technology

Massachusetts

Institute of

Technology

Purdue University

SEA Corp.

Solar Cells, Inc.

Solarex Corporation

SunPower

Corporation

University of

Southern California

National Renewable

Energy Laboratory

Sandia National

Laboratories
What Was Accomplished

Produced $22 \%$ efficient silicon cells at 100 suns for point-focus concentrators.

Fabricated an $8 \%$ efficient, $38-\mathrm{cm}^{2}\left(5.9-\mathrm{in}^{2}\right)$ thin-film CIS submodule using Se vapor source.

Fabricated a $7.7 \%$ efficient, $3600-\mathrm{cm}^{2}\left(3.9-\mathrm{ft}^{2}\right)$ thin-film CdTe module by spraying.

Fabricated a $6.9 \%$ efficient $900-\mathrm{cm}^{2}\left(1-\mathrm{ft}^{2}\right)$ thin-film CIS module.

Demonstrated silicon surface passivation by halogens (iodine and bromine) yielding recombination velocities comparable to the best oxide interface $(2.1 \mathrm{~cm} / \mathrm{s})$.

Demonstrated light trapping in thin GaAs solar cell structures, a prerequisite for observation of photon recycling effects.

Produced a line-focus, extruded acrylic lens having an optical efficiency of $85.5 \%$.

Fabricated a $7.7 \%$ efficient, $7200-\mathrm{cm}^{2}\left(8-\mathrm{ft}^{2}\right)$ thin-film CdTe module by modified close-spaced sublimation. Also, installed 1-kW thin-film CdTe array for testing.

Produced $800-\mathrm{cm}^{2}\left(.86-\mathrm{ft}^{2}\right)$ prototype triple-junction a-Si module with stabilized efficiency of $8.8 \%$.

Fabricated $18 \%$ efficient silicon cells at 10 suns using new low-cost buried-contact cell technology.

Fabricated $25.6 \%$ efficient silicon cells at 72 suns for point-focus concentrators.

Demonstrated low temperature growth of GaAs with background carrier concentration in the mid- $10^{15} \mathrm{~cm}^{3}$ range.

Adapted close-spaced sublimation deposition method to fabricate $10.6 \%$ efficient CdS/CdTe devices on industrial-grade, soda-lime glass.

Discovered a technique for photoluminescence analysis of silicon at room temperature using a Fourier Transform Infrared Spectrometer.

Established computational techniques using first principles for calculation of systems with up to 1000 atoms.

Fabricated and successfully tested a c-Si cell with an emitter-wrap-through design.

Produced a c-Si cell with efficiencies of $18 \%$ under no concentration and $20 \%$ under a concentration of 40 suns using commercial-grade $(\mathrm{Cz})$ silicon made by Siemens Solar Industries.
Why It Was Important

Demonstrates high-efficiency cells produced with a commercial production process.

First CIS submodule fabricated without the use of $\mathrm{H}_{2} \mathrm{Se}$ gas.

Shows progress toward manufacturing low-cost, thin-film CdTe modules by spraying - an industrial process with low capital requirements.

Demonstrates the potential of a two-stage process for CIS module fabrication.

Control of surface recombination is needed for high efficiency solar cells and for rapid, reproducible electro-optical characterization of materials.

If photon recycling (recombination-reemission mechanism) can be exploited, efficiencies can be achieved that are $10 \%$ higher than those predicted by models.

Demonstrates high efficiency for a low-cost extruded lens.

Shows rapid progress of potentially low-cost, thin-film technology. World's first 1-kW thin-film CdTe array.

Highest stable efficiency to date for this type of module; higher stabilized efficiency is key for larger-power applications.

Demonstrates high-performance cells for low-concentrations using a commercial one-sun technology.

Demonstrates high performance of silicon concentrator cells fabricated in a pilot production line.

Low-temperature atomic layer epitaxy opens a wider range of low-cost substrates.

Supports major producers of CdS/CdTe devices, because they use substrates made of soda-lime glass.

Greatly reduces the cost and time required for optical characterization of silicon by eliminating use of cryogenic helium and its related low-temperature equipment.

Permits analysis of nonhomogeneous systems including dislocations and grain boundaries.

Verifies design with potential of achieving $18 \%-20 \%$ efficiency on commercial-grade ( $\mathrm{C} z$ or multicrystalline) silicon.

Demonstrates the performance potential of Siemens' material. 


\section{Summary of PV Program Services}

NREL and Sandia have unique facilities and expertise that support the private sector. These services are available to contractors and others committed to improving photovoltaics technology. Some of the capabilities available are listed below. For more information, contact one of the sources listed on the back cover of this document.

\section{Measurement and Performance}

Both NREL and Sandia perform thousands of state-of-the-art measurements and analyses each year for the photovoltaic community. These include analyzing materials, characterizing devices, evaluating fabrication problems, and modeling for computers. Both laboratories often provide unofficial, impartial confirmation of cell performance, as well as calibrations of photovoltaic reference cells.

\section{Materials Synthesis and Processing Laboratories}

The facilities at NREL provide a host of options for crystal growth, thinfilm deposition, and cell component and materials processing development. In these facilities, researchers work to improve PV performance by exploring new approaches to electrical contacting, anti-reflection coatings, durable cell and module packaging and semiconductors.

\section{Device Fabrication Laboratories}

The Photovoltaic Device Fabrication Laboratory at Sandia is available to assess new solar cell designs and fabrication processes using small-scale versions of the most commonly employed cell fabrication equipment and computer-controlled data collection. Industry can now test new ideas without having to shut down production lines or build a new laboratory. Proprietary processes are protected from disclosure.

Similarly, facilities at NREL are being used to develop devices to improve our understanding of crystallinesilicon solar cells. NREL researchers are also working to improve cells made of amorphous silicon, copper indium diselenide, cadmium telluride, thin-film silicon, gallium arsenide, and other group III-V materials.

\section{Solar Radiation Research}

The response of different types of solar cells depends on the intensity and spectral distribution (color) of the sunlight striking them. NREL's Solar Radiation Resource Assessment Project provides researchers in the PV community with solar radiation data, models, and algorithms to help predict device performance, optimize device design, and improve instrumentation for measuring solar radiation, as well as other services.

\section{Module and Performance Testing and Engineering}

Both NREL and Sandia maintain facilities to test the reliability and performance of modules under simulated and outdoor conditions. Working with the private sector, the PV Program maintains a database to track advances in design and performance, to develop evaluation criteria and test methods, and to design new 


\section{Sunrayce}

Much more than just a car race, Sunrayce is a 2-year educational program for college-level science and engineering students. The PV Program is one of several sponsors of Sunrayce, which challenges students to design, build, and race electric cars powered by sunlight. Over 2000 students participated in the hands-on designing of PV cars in 1993. The race began in Texas and finished in Minnesota, covering over $1760 \mathrm{~km}(1110 \mathrm{mi})$ in 7 days. Preparations for the 1995 Sunrayce are already under way. test and measurement techniques. Sandia focuses on developing and testing balance-of-systems components and the reliability of concentrator systems. NREL emphasizes reliability research, exploratory qualification testing, systems engineering and testing for flat-plate PV technologies, and the development of module/system codes and standards.

\section{Systems and Applications}

The Design Assistance Center at Sandia is an important resource for technical information about PV systems. The staff helps prepare requests for proposals, reviews and evaluates system design and performance, leads workshops and seminars, identifies applications for photovoltaics, and performs feasibility studies.

Staff at NREL provide analytical and applications development support and foster coordinated approaches to market conditioning and project development activities. These activities complement the work at Sandia and include international support; education, technical assistance, and training; market, economic, regulatory, and rate analysis; technology characterization; and technology transfer.

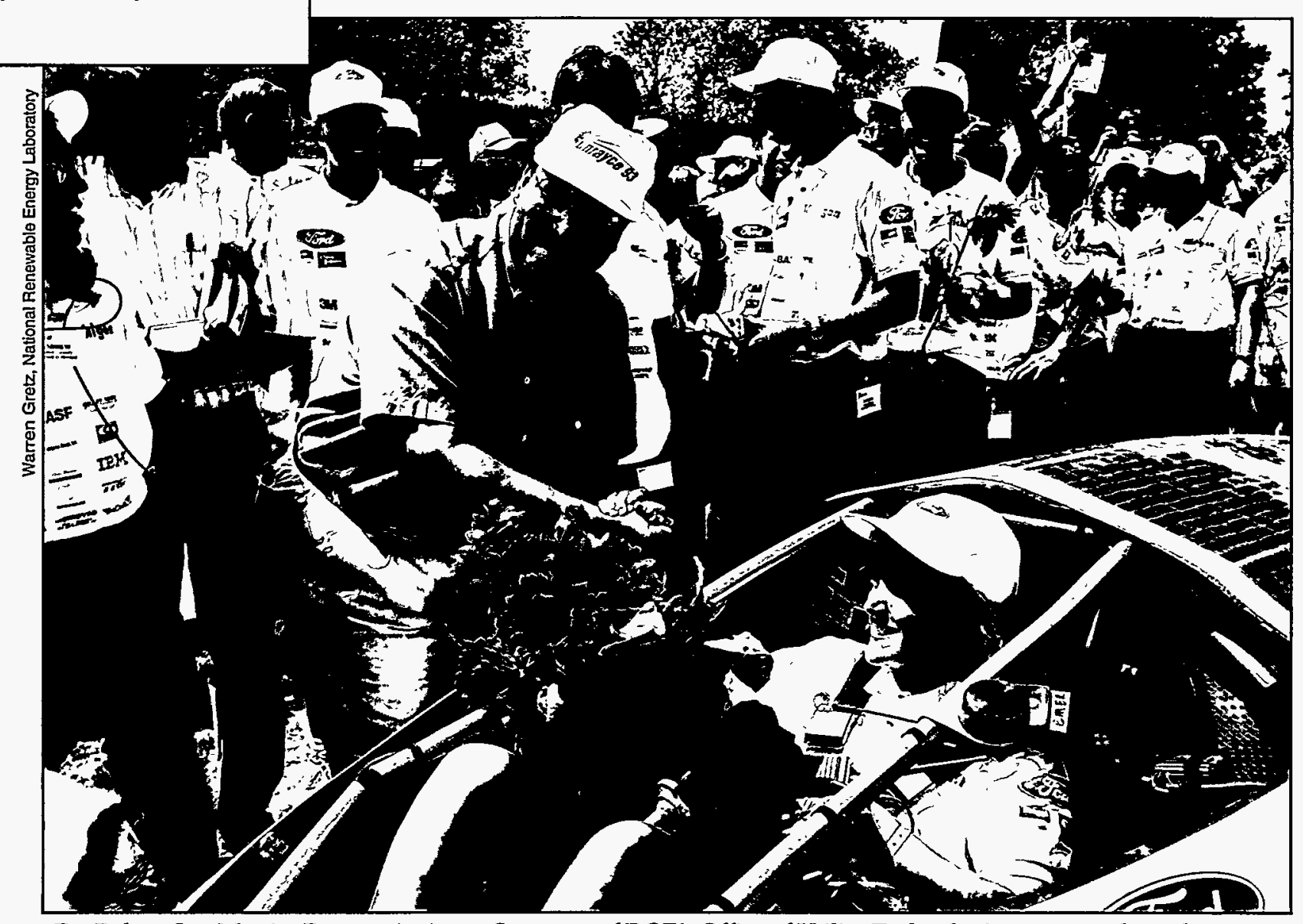

- Dr. Robert San Martin, Deputy Assistant Secretary of DOE's Office of Utility Technologies, congratulates the University of Michigan's winning driver at the finish line of Sunrayce '93. 


\section{KEY CONTACTS}

U.S. Department of Energy

James E. Rannels, Director

Photovoltaics Technology Division CE-131

1000 Independence Avenue, SW

Washington, DC 20585

(202) $586-1720$

FAX (202) 586-5127

National Renewable Energy Laboratory

Thomas Surek, Program Manager

Photovoltaics Division

1617 Cole Boulevard

Golden, CO 80401-3393

(303) 384-6471

FAX (303) 384-6530

Sandia National Laboratories

David Hasti, Projects Manager

Photovoltaics Division 6223

Albuquerque, NM 87185-5800

(505) 844-8161

FAX (505) 844-6541

\section{NOTICE}

$\checkmark$ This report was prepared as an account of work sponsored by an agency of the United States govemment. Neither the United States government nor any agency thereof, nor any of their employees, makes any warranty, express or implied, or assumes any legal liability or responsibility for the accuracy, completeness, or usefulness of any information, apparatus, product, or process disclosed, or represents that its use would not infringe privately owned rights. Reference herein to any specific commercial product, process, or service by trade name, trademark, manufacturer, or otherwise does not necessarily constitute or imply its endorsement, recommendation, or favoring by the United States government or any agency thereof. The views and opinions of authors expressed herein do not necessarily state or reflect those of the United States government or any agency thereof.

Printed in the United States of America Available from:

National Technical Information Service

U.S. Department of Commerce

5285 Port Royal Road

Springfield, VA 22161

Price: Microfiche A01, Printed Copy A03

Codes are used for pricing all publications. The code is determined by the number of pages in the publication. Information pertaining to the pricing codes can be found in the current issue of the following publications which are generally available in most libraries: Energy Research Abstracts (ERA); Govemment Reports Announcements and Index (GRA and I); Scientific and Technical Abstract Reports (STAR); and publication NTIS-PR-360 available from NTIS at the above address.

Printed with renewable source ink on paper containing at least $50 \%$ wastepaper.

\section{Produced for the}

U.S. Department of Energy

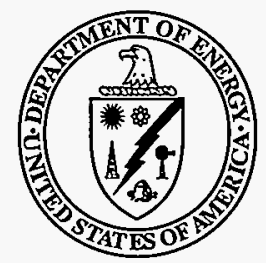

1000 Independence Avenue, SW Washington, DC 20585

by the National Renewable Energy Laboratory, a ḊOE national laboratory.

DOE/CH10093-264

DE94000246

February 1994 